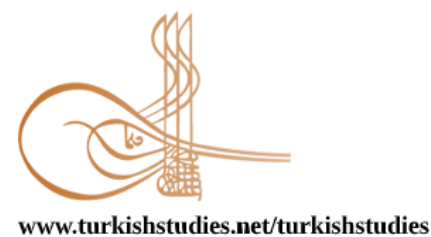

Turkish Studies

Research Article / Araștırma Makalesi

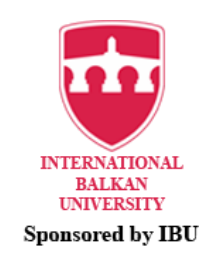

\title{
Selman Ada'nın Aşk-ı Memnu Operasının Müziği, Dramatik Yapısı ve Karakterleri
}

\author{
The Music, Dramatic Structure and Characters of Selman Ada's Aşk-1 Memnu Opera
}

\author{
Bülent Yüksel*
}

\begin{abstract}
Aşk-ı Memnu, the first "real" Turkish novel and one of the masterpieces of our literature, has been a source of inspiration for Tarık Günersel and Selman Ada, one of the most important artists of our country. Based on this novel, the libretto written by Tarı Günersel with a new fiction and plot; It was composed by Selman Ada, one of the most valuable composers in the field of opera in our country, with a melodic approach and a individual musical language. Examination of Aşk-ı Memnu opera within the framework of music, dramatic structure and characters is the subject of this research. As a result of the literature review, no study was found in which Aşk-ı Memnu opera was examined within this framework. This issue constitutes the problem situation of the research. It is considered that this study, which focuses on the Aşk-ı Memnu opera, which makes a great contribution to our national opera repertoire and is related to one of the most important works of our literature, will be important in terms of being a source of information for composers who want to produce works in the field of opera and for all researchers who will play a role in the development of our national music. In this direction, the aim of the study is to examine the Aşk-ı Memnu opera comparatively with the novel of the same name, to reveal the differences and the points emphasized in the libretto; To contribute to the literature by examining its dramatic structure, characters and music. In this study, which made use of qualitative research methodology, the data that has been obtained via the "document study" method was assessed with "descriptive" and "content-based" analysis techniques. Based on the score of the opera, its music, and its libretto as the basis, the dramatic structure and features of the characters are resolved. At the end of the research; In the libretto written by Tarık Günersel, it is seen that social and political issues that Halit Ziya Uşaklıgil could not touch due to his period were mentioned. Coercive management is clearly emphasized. It is seen that Selman Ada skillfully combines the opportunities provided by Western music and Turkish music on a common denominator in Aşk-ı Memnu opera. It can be said that a musical approach that progresses in harmony with the plot, supports drama and emotions. The melodic approach and elements of Turkish music make it easier to follow the opera. It is remarkable that arias are outnumbered than other operas.
\end{abstract}

Structured Abstract: Aşk-ı Memnu, the first "real" Turkish novel and one of the masterpieces of our literature, has been a source of inspiration for Tark Günersel and Selman Ada, one of the most important artists of our country. Based on this novel, the libretto written by Tarı Günersel with a new fiction and plot; It was composed by Selman Ada, one of the most valuable composers in the field of opera in our country, with a melodic approach and a individual musical language. Examination of Aşk-ı Memnu opera within the framework of music, dramatic structure and characters is the subject of this research. As a result of the

\footnotetext{
${ }^{*}$ Dr. Türkiye Cumhuriyeti Milli Savunma Bakanlığ 1

Dr. Republic of Türkiye Ministry of National Defence

ORCID 0000-0002-0797-3871
}

bulentyukselbs@gmail.com

Cite as/ Atıf: Yüksel, B. (2021). Selman Ada'nın Aşk-ı Memnu operasının müziği, dramatik yapısı ve karakterleri

. Turkish Studies, 16(6), 1763-1787. https://dx.doi.org/10.7827/TurkishStudies.52430

Received/Geliş: 23 August/Ağustos 2021

Accepted/Kabul: 25 December/Aralık 2021

Checked by plagiarism software

Published/Yayın: 30 December/Aralık 2021

CC BY-NC 4.0 
literature review, no study was found in which $A s ̧ k-\imath$ Memnu opera was examined within this framework. This issue constitutes the problem situation of the research. It is considered that this study, which focuses on the Aş-ı Memnu opera, which makes a great contribution to our national opera repertoire and is related to one of the most important works of our literature, will be important in terms of being a source of information for composers who want to produce works in the field of opera and for all researchers who will play a role in the development of our national music. In this direction, the aim of the study is to examine the Assk- $\iota$ Memnu opera comparatively with the novel of the same name, to reveal the differences and the points emphasized in the libretto; To contribute to the literature by examining its dramatic structure, characters and music. In this study, which used the qualitative research method, the data obtained by the "document review" method; "descriptive" and "content" were evaluated with data analysis techniques. Based on the score of the opera, its music, and its libretto as the basis, the dramatic structure and featured of the characters are resolved.

The skeleton of this novel consists of two plots, consisting of Bihter being dragged into forbidden love and Nihal being dragged into loneliness. At the center of these two plots are women. In the novel, the main struggles take place between women, and women usually trigger important events to take place.

Different characters are placed in the center of the plot. The author successfully enables the reader to look at the novel from the perspective of different characters. In this context, each character deserves to be scrutinized separately. Examinations with an approach where a single character is at the center may be inperfect and without depth.

In two different genres such as novel and opera, it is natural to see various changes such as not including the subject in one genre in the other genre or new additions in the rewriting of the same work.

At the end of the this research; In the libretto written by Tarı Günersel, it is seen that the social and political issues that Halit Ziya Uşaklıgil could not touch due to his period were mentioned. Coercive management is clearly emphasized.

The most striking difference between the two genres is that Adnan Bey and his family, who have a Western lifestyle in the novel, have a conservative lifestyle in the Opera.

In the libretto, expressions reminiscent of surrealism, which has no connection with the plot, are sometimes encountered. For example, in some dialogues, bonbon candy is mentioned, which has nothing to do with the topic.

Unlike The Novel, in Opera, Bihter tells her mother that she is pregnant. This addition was made to make Bihter's suicide drift more credible in today's world.

It is seen that Selman Ada skillfully combines the opportunities provided by Western music and Turkish music on a common denominator in $A s ̧ k-\imath$ Memnu opera. It can be said that a musical approach that progresses in compatible with the plot, supports drama and emotions.

In $A s ̧ k$ - $M e m n u$, an original musical craftsmanship that cannot be reconciled with any movement or style stands out. Mainly tonal but distinctive on harmonic ground; and sometimes an approach dominated by fourths and seconds is seen.

The melodist approach in the work and the musical materials belonging to this geography make it easier for the listener to follow the piece.

It is seen that the arias, which can be considered as a "pause" in the progression of the plot, are designed in a wide range of ways, from bass to soprano, to evaluate all registers of the human voice. There are 13 arias in Aşk-ı Mетnu opera. It is remarkable that arias are outnembered than other operas.

It is quite remarkable that in the orchestra staff, Turkish music instruments such as zilli def and kudum are included in addition to the traditional instruments of symphony orchestras and that materials such as whips are used as instruments.

Keywords: Music, Selman Ada, Aşk-ı Memnu, opera, Halit Ziya Uşaklıgil, forbidden love

Öz: İlk "gerçek" Türk romanı ve edebiyatımızın şaheserlerinden biri olan Aşk-ı Memnu, ülkemizin en önemli sanatçılarından Tarık Günersel ve Selman Ada'nın ilham kaynağı olmuştur. Bu romandan hareketle, Tarık 
Günersel'in yeni bir kurgu ve olay örgüsüyle yazdığı libretto; ülkemizin opera alanındaki en değerli bestecilerinin başında gelen Selman Ada tarafından ezgisel bir yaklaşım ve özgün bir müzik diliyle bestelenmiştir. Aşk-ı Memnu operasının müzik, dramatik yapı ve karakterler çerçevesinde incelenmesi bu araştırmanın konusunu oluşturmaktadır. Literatür taraması sonucunda, Aşk-ı Meтnu operasının bu çerçevede incelendiği bir çalışma bulunamamıştır. Bu husus araştırmanın problem durumunu oluşturmaktadır. Ulusal opera repertuvarımıza büyük katkı sağlayan ve edebiyatımızın en önemli yapıtlarından biri ile "komșuluk" ve

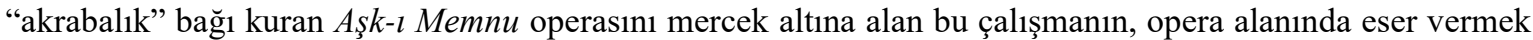
isteyen besteciler ve ulusal müziğimizin gelişmesinde rol oynayacak tüm araştırmacılar için bilgi kaynağ olması bakımından önemli olacağı değerlendirilmektedir. Bu doğrultuda çalışmanın amacı Aşk-ı Memnu operasını aynı adlı roman ile karşılaştırmalı olarak inceleyerek, farklılıkları ve librettoda vurgulanan hususları ortaya çıkarmak; dramatik yapısı, karakterleri ve müziğini inceleyerek literatüre katkı sağlamaktır. Nitel araştırma yönteminden yararlanılan bu çalışmada, "doküman inceleme" yöntemiyle elde edilen veriler; "betimsel" ve "içerik" veri analiz teknikleriyle değerlendirilmiştir. Partisyonu temel alınarak Opera'nın müziği, librettosu temel alınarak ise dramatik yapı ve karakterlerin özellikleri çözümlenmiştir. Araştırma sonunda; Tarık Günersel'in yazdığı librettoda, dönemi gereği Halit Ziya Uşaklıgil'in değinemediği toplumsal ve siyasî konulara değinildiği görülür. Baskıcı yönetim açık açık vurgulanır. Selman Ada'nın, Aşk-ı Memnu operasında, Batı müziği ve Türk müziğinin sağladığı imkânları ortak paydada ustaca birleştirdiği görülür. Olay örgüsü ile uyumlu bir şekilde ilerleyen, dramayı ve duyguları destekleyen bir müzikal yaklaşımın gözetildiği söylenebilir. Melodist yaklaşım ve Türk müziğine ait unsurlar, Opera'nın takip edilmesini kolaylaştırmaktadır. Aryaların diğer operalara kıyasla sayıca fazlalığı dikkat çekicidir.

Anahtar Kelimeler: Müzik, Selman Ada, Aşk-ı Memnu, opera, Halit Ziya Uşaklıgil, yasak aşk

\section{Giriş}

Halit Ziya Uşaklıgil'in yazdığı Aşk-ı Memnu ilk olarak 9 Şubat 1899-17 Mayıs 1900 tarihleri arasında Servet-i Fünun dergisinde tefrika edilmiştir. 1901 yılında ise Arap harfleriyle kitap olarak basılmıştır. 1939 yılındaki yeni harflerle ilk baskısında kitap, yazar tarafindan tekrar gözden geçirilmiş ve Türkçeleştirilmiştir. Servet-i Fünun edebiyatının en güçlü yazarlarından biri olan Halit Ziya Uşaklıgil bu romanla birlikte büyük bir ün kazanmıştır. Kantemir (2019, s. 227) Aşk-ı Memnu'nun yalnız bu devir edebiyatının değil aynı zamanda bütün Türk edebiyatının şaheseri sayıldığını belirtir. Fethi Naci de Uşaklıgil'in en başarılı romanı olarak gördüğü $A s ̧ k-\imath$ Memnu'nun ilk "gerçek" Türk romanı olduğunu ifade etmektedir (Kanan, 2007, s. 15).

Roman 19. yüzy1lın sonunda yaşayan zengin ve görece tüketici bir toplum katmanının simgesi olan bir ailenin yaşamını anlatmaktadır. Suut Kemal Yetkin, Aşk-ı Memnu'nun yazıldığı dönemde, başta Boğaziçi olmak üzere bazı çevrelerinde romandaki Melih Bey Takımını anımsatan ailelerin olduğunu belirtmektedir (Kanan, 2007, s. 13).

Maden (2008, s. 80) erkeklerin gölgesinde yaşayan kadınların, toplumun yaşam alanına taşınarak ön plana çıkarılması gibi birçok yeniliğin bu romanla birlikte edebiyatımıza kazandırıldığını belirtir.

İlk "gerçek" Türk romanı ve edebiyatımızın şaheserlerinden biri olan Aşk-ı Memnu, kıymetli yazar Tarık Günersel ve değerli bestecimiz Selman Ada’ya da ilham kaynağı olmuştur.

Aşk-ı Meтnu romanının yazılışının yüzüncü yılı olan 2000 yılında, Tarık Günersel'in romandan hareketle yazdığı libretto, aynı yıl Selman Ada tarafindan opera olarak bestelenmiştir.

Tüm bunlardan hareketle bu çalışmanın amacı, Aşk-ı Memnu operasını aynı adlı roman ile karşılaştırmalı olarak incelenmesi, farklılıklar ve librettoda vurgulanan hususların ortaya çıarılması; dramatik yapı, karakterler ve müziğinin incelenmesidir. Belirtilen amaca ulaşmak için bu çalışmanın yanıt aradığı sorular şöyle belirlenmiştir:

- Aşk-ı Meтnu romanının konusu nedir?

- Aşk-ı Meтnu romanındaki kişilerin özellikleri nelerdir? 
- Mekân, olay örgüsü ve yapısal kurgusu bakımından Aşk-ı Memnu romanında öne çıkan tema, kavram, çatışma ve dikkat çeken diğer özellikler nelerdir?

- Dramatik yapı, kişi ve olay örgüsü bağlamında Roman ve Opera arasındaki farklılıklar nelerdir?

- Aşk-ı Метпи operasının müzikal yapısının özellikleri nelerdir?

\section{Yöntem}

$\mathrm{Bu}$ makalede, nitel araştırma yöntemlerinden faydalanılmıştır. Aşk-ı Memnu'nun şef partisyonu ve video kaydı ile "doküman inceleme" metoduyla elde edilen diğer veriler, "betimsel" ve "içerik" analiz süreçlerine tabi tutularak; tarafımızca yorumlanmıştır. Makalenin her aşamasında literatür taraması yapılmıştır.

\section{Bulgular ve Yorum}

\section{Aşk-ı Memnu Romanının Konusu}

"Melih Bey Takımı" olarak bilinen ailenin bir üyesi olan Firdevs Hanım, gösterişli ve rahat yaşamayı seven, erkeklerin peşinde koştuğu bir kadındır. Peyker ve Bihter adında iki kızı vardır. Firdevs Hanım, çocuklarının doğumu nedeniyle gençliğini yaşayamadığını düşünerek kocası ve kızlarına içten içe bir öfke beslemektedir. Kocası, Firdevs Hanım'ın yaşantısından hoşnut olmadığından sıklıkla tartışıllar. Zamanla kızları büyür. Büyük kızı Peyker, Nihat Bey ile evlenmiştir. Bihter'e ise zengin ve eğitimli bir dul olan Adnan Bey talip olur. Adnan Bey’in kendisi ile evlenmesini ümit eden Firdevs Hanım bu teklif karşısında hayal kırıklığı yaşar. Önceleri kabul etmese de sonunda bu evliliğe razı olur. Bihter, annesine benzememek, rahat ve namuslu bir hayat yaşamak hayaliyle kendisinden yaşça çok büyük olan Adnan Bey ile evlenmeyi, çocuklarının da üvey annesi olmayı kabul eder. Adnan Bey'in çocukları Nihal ve Bülend ile kendi anneleri kadar ilgilenme hevesindedir. Nihal 15, Bülend 9 yaşındadır. Adnan Bey'in eşi, Bülend'in doğumundan hemen sonra hayatını kaybetmiştir. Babasına çok düşkün ve hassas bir çocuk olan Nihal, annesinin ölümünden çok etkilenmiş olduğundan narin bir çiçek gibi gözetilmektedir. İstanbul ve Türk ailesine meraklı olan Matmazel Courton, dört yaşından itibaren Nihal'in mürebbiyeliğini (dadı ve eğitimci) yapmaktadır. Matmazel Courton, ilk gördüğü andan itibaren Nihal ile anne kız ilişkisi kadar güçlü bir gönül bağ 1 kurmuştur. Nihal de kardeşi Bülend'i kendi çocuğuymuş gibi koruyup, kollar. Adnan Bey ile Nihal'in dadısı Matmazel Courton, bu evliliğe en çok Nihal'in tepki vereceğini düşünmektedirler. Matmazel Courton, Nihal'i düşündüğü için başta bu evliliğe sıcak bakmaz. Adnan Bey, Nihal'e konuyu anlatma ve onu ikna etme görevini Matmazel Courtan'a verir. Matmazel, bu evliliğin herkes için olumlu olacağını anlatarak Nihal'i ikna eder ve onayını alır. Evliliğin ilk bir iki yılında kimse sorun yaşamaz. Ancak Bihter, özellikle yaş farkı nedeniyle Adnan Bey'de aradığı aşkı ve ilgiyi bulamadığını farketmeye başlar. Zamanla Adnan Bey'in genç ve çapkın yeğeni Behlül'e ilgi duymaya başlar. Behlül, Galatasaray Lisesi'nde yatılı olarak okumakta, haftada bir gün de amcasının evinde kalmaktadır. Behlül'ün de genç ve güzel Bihter'e ilgi duymasıyla bir yasak başlar. Nihal de başta kardeşi Bülend olmak üzere sevdiklerinin Bihter tarafından yalıdan ve kendisinden uzaklaştırılması gibi nedenlerle zamanla Bihter'den uzaklaşmaya ve ondan nefret etmeye başlar. Firdevs Hanım, Bihter ile Behlül arasındaki bu yasak aşkı farketmiştir. Behlül'ü, kızından ayırmak için Behlül ile Nihal'in evlenmesi fikrini ortaya atar. Behlül zaten Bihter'den sıkılmaya başlamış ve ondan uzaklaşmaya başlamıştır. Bu fikir, Behlül ve Nihal tarafindan da kabul görür. Bihter, Behlül ile Nihal'in evliliğini engellemek için elinden geleni yapar, ancak başaramaz. Adnan Bey'in de onayıyla bu evlilik gerçekleşir. "Aldatılmış" olmanın öfkesiyle gözü kararan Bihter, herşeyi Adnan Bey'e anlatacağını ifade eder, ancak bu düşüncesini gerçekleştirmez. Öte yandan yalının çalışanlarından birinin oğlu olan Beşir, Nihal'i gizliden gizliye sevmekte ve yasak aşkı da bilmektedir. Nihal, Firdevs Hanım'ın Behlül'ü uyarmak için yazdığı mektubu okuyarak bu yasak aşktan şüphelenmeye başlar. Bu şüphenin üzerine bir de Behlül ile Bihter'in yasak aşkı belli eden konuşmalarını duyunca sinir krizi geçirerek bayılır. Beşir, 
kızının neden bayıldığını anlamaya çalışan Adnan Bey’e yasak aşka dair bildiği herşeyi anlatır. Annesine benzememek, varlıklı yaşayarak iyi bir eş olmak için başladığı evlilik serüveninin sonunda kocasını aldatan kadın durumuna düşen Bihter, tüm bu yaşananlar neticesinde kendi canına kıyar. Behlül ise kaçar. Birkaç ay süren rehabilitasyon sürecinden sonra nihayet Adnan Bey ile kızı Nihal tıpkı en baştaki gibi eski mutlu ve huzurlu günlerine geri dönerler. Daha önce yalıdan gönderilmiş olan Matmazel Courton, Şakire Hanım ve Süleyman Efendi geri dönecek, Bülend okulda yatılı kalmayacaktır. Bu "mutlu" sondaki tek üzücü olay ise Beşir'in yakalandığı amansız hastaliktan kurtulamayarak hayata veda etmesidir.

\section{Roman Karakterleri}

Arslanoğlu (2017, s. 251) Ahmet Hamdi Tanpınar'ın Aşk-ı Memnu'yu bir satranç oyununa benzettiğini aktarmaktadır. Olay örgüsünün merkezine yer yer farklı karakterler yerleşmektedir. Yazar, okuyucunun Roman'a farklı karakterlerin penceresinden bakmasını başarıyla sağlamaktadır. Bu bağlamda her bir karakter ayrı ayrı mercek altına alınmayı hak etmektedir. Tek bir karakterin merkezde olduğu bir yaklaşımla yapılacak incelemelerin eksik ve sığ kalacağı değerlendirilmektedir.

\section{Adnan Bey}

Zengin ve elli yaşlarında dul bir beyefendi olan Adnan Bey, en başta kızı Nihal olmak üzere çocuklarına bağlı, ölçülü ve iyi niyetli bir insandır. Evlendikten sonra Bihter'e de büyük bir sevgiyle bağlanmıştır. Ancak zamanla bu sevginin karşılıksız olduğunu farketmiştir. En büyük merakı tahta üzerine oymacılıktır. Roman'da servetinin ve kazancının kaynağı belirtilmemektedir.

\section{Behlül}

Adnan Bey'in genç ve çapkın yeğenidir. Babası vilayetlerden birine memur olup gidince Galatasaray Lisesi'nde yatılı olarak okumaya başlamıştır. Haftada bir gece de Adnan Bey'in yalısında kalmaktadır. Nihal'den sekiz yaş büyük olan Behlül, onun ağabeyi gibidir. Sıklıkla çocuksu kavgalar ettiği Nihal'in çocukluklarıyla alay etmekte, ancak nihayetinde onun gönlünü almaktadir.

Yüzeysel, eğlenmeyi seven ve ahlaki değerleri düşük bir karakter olan Behlül, aşk1 yaşamaktan çok, yaşadığı aşkı süsleyerek başkalarına anlatmayı sevmektedir. Arslanoğlu (2017, s. 259) Behlül'ün aşk1 aramaktan çok, onu tükettiğini belirtir. Onun için eğlenmek, eğleniyor görünmek anlamına gelmektedir. Çevresindekilere kendi zevki için kullanılacak araçlar kadar önem verir. Paranın büyük bir güç olduğunu düşünür.

Romanın yazarı Uşaklıgil, Behlül için "Benim özelliklerini tanıdığım bir, iki, belki üç gençten toplanmış bir gençtir” demektedir (Kanan, 2007, s. 14).

Arslanoğlu (2017, s. 258), özellikle yasak aşk ile birlikte Behlül karakterinin ön plana çıkartılmasını, romanın satranca benzeyen kurgusunda Halit Ziya'nın önemli bir hamlesi olarak görür.

\section{Beşir}

Afrika asıllıdır. Roman'da küçük habeşli olarak nitelendirilir. Yalıdaki gündelik işlere yardımcı olur. Nihal'e karşı büyük bir sevgi beslemektedir. Roman'ın sonunda, yasak aşk hakkında bildiği herşeyi Adnan Bey'e anlatarak, Bihter'i intihara sürükleyen olay örgüsünü başlatır. Roman'ın görece mutlu sonundaki tek üzücü olay Beşir'in hayatını kaybetmesidir.

\section{Bihter}

Bihter, Adnan Bey ile öncelikle serveti için evlenen, yirmili yaşlarında genç ve güzel bir kadındır. Bihter'i Roman'da öne çıkaran şey onun yaşadığı trajedidir. Zevkine düşkün, bencil ve 
sadakat konusunda kötü bir üne sahip olan annesine benzememek için mücadele etmesine rağmen, yaşadığı yasak aşk nedeniyle onun durumuna düşmüştür. Buna karşın hayatına son vermesi bile annesinin durumuna düşmeyi kabul etmediğini göstermektedir. Roman'a Bihter açısından bakıldığında kaderini değiştiremeyen bir insanın trajedisinden bahsedilebilir.

Bihter'in, yasak aşka sürüklenişi ve bu sürüklenişin arkasındaki elde olan ve olmayan nedenler, yazar tarafindan çok başarılı bir kurguyla okuyucuya sunulmuştur.

Moran (1998, s. 55), bir roman kişisinin değişimini, belli bir zaman süresi içinde meydana gelen bir gelişme olarak sunmanın, Uşaklıgil'den önceki yazarlarda görülen bir yöntem olmadığını belirtir.

Namuslu, saygın bir kadın olmak isteyen, annesi gibi olmamak için mücadele eden Bihter; içinde bulunduğu ortamın koşulları, sevme ve sevilme isteği nedeniyle kendisini hiç istemese de aldatan kadın konumunda bulmaktadır. Elbetteki bu sürüklenişin nedenleri vardır. Moran (1998, s. 55), Bihter'in bu yasak aşka doğru kaçınılmaz sürüklenişinin, Uşaklıgil tarafından özellikle psikolojik nedenler üzerinde durularak belirtilmeye çalışıldığını ifade eder. Moran'a (1998, s. 55) göre Bihter üç aşamadan geçer:

1) Genç kızlık emellerine kavuşacağı umuduyla zengin Adnan Bey ile evlenen ve görevini yapmaya çalışan Bihter.

2) Hayal kırıklığına uğradığı için mutluluğu yasak bir sevgide bulan Bihter.

3) Bıkıldığını ve terkedildiğini anlayarak kıskançlıkla boğulan ve intikam için her şeyi yıkıp intihar eden Bihter.

Yasak aşka giden yolda Bihter'in eleştirilebileceği belki de tek şey, serveti için Adnan Bey ile evlenmeyi kabul etmesidir. Bu evlilik her ne kadar konfora ulaşma ve annesinden kurtulma düşüncesiyle yapılsa da; Bihter, Adnan Bey'i seveceğine, onun çocuklarına iyi bir anne olacağına, sadık ve saygın bir kadın olacağına gerçekten inanmaktadır. Bu kabul edilebilir genç kızlık hayalleri ve masum düşünceler; Bihter'in, Adnan Bey ile evlenmeyi kabul etmesine yönelik okuyucu tepkisinin dozunu düşürecek niteliktedir. Birkaç yıl geçtiğinde bu evlilik, özellikle yaş farkı nedeniyle Bihter'in mutlu olmasına yetmemiştir. Bihter'i yasak aşka iten şey, Behlül'e olan sevgisinden çok sevilmeye olan ihtiyacıdır. Bu bağlamda Moran (1998, s. 56), yazar tarafindan Bihter'in ahlaksız bir kadın olarak değil de, trajik bir karakter olarak işlendiğini belirtir. Moran (1998, s. 59), nedenleri farklı olsa da Bihter ile Madam Bovary'deki Anna Karenina'nın aynı sonu paylaştıklarını düşünmektedir.

Bihter'in, annesi Firdevs Hanım'dan Behlül ve Nihal'in evlenmelerine engel olmasını istediği diyolaglardaki şu sözler, yaşanan acıyı yansıtması bakımından çok etkileyicidir: "Lakin Yarabbi! Anlasanıza, ölüyorum. Onların gözümün önünde seviştiklerinden, gözümün önünde...Ben işkenceler içinde kıvranırken, onların saadetlerinden ölüyorum." (Uşaklıgil, 2000, s. 385-386).

\section{Bülend}

Nihal'in erkek kardeşidir. Bülend doğduğunda Nihal, onun varlığından rahatsız olarak huzursuzluk çıkarır. Bunun üzerine babası ve yalıdakiler, Nihal'e "Bülend'i sana vereceğiz, onu sen terbiye edeceksin, yanında yatıracaksın, soyup giydireceksin, Bülend artık senin olacak" diyerek onun rahatsızlığına son verirler. Nihal artık adeta Bülend'in annesidir. Onu herkesten esirgeyip, kıskanır.

Bülend, romanda çevresindeki olumsuzluklardan habersizdir. Nihal ile Bihter arasındaki çatışma da, Bülend'in yatağının Nihal'in odasından başka bir odaya taşınmasıyla başlar. 


\section{Firdevs Hanım}

Bihter'in annesi olan Firdevs Hanım, henüz on sekiz yaşındayken Rumeli sahilinin zarif bir yalısına gelin olarak gider. Bu evlilikten sonra kocasından "Firdevs Hanım'ın Beyi" olarak bahsedilir (Uşaklıgil, 2000, s. 22). Firdevs Hanım 45 yaşına kadar İstanbul'daki bütün mesirelerin en tanınan simalarındandır. Kocası, Firdevs Hanım'ın toplum içindeki rahat tavırlarından rahatsızdır. Bu nedenle sıklıkla tartışırlar. Kocası bir gün Firdevs Hanımın kendisini aldattığını bir mektup vesilesiyle öğrenir ve yaşanan tartışma sırasında kalp krizi geçirerek hayata veda eder.

Roman'da Firdevs Hanım, yaşlanmayı kabullenemeyen, yaşıtlarından farklı olarak gözü hala zevk ve eğlencede olan, dahası kızlarının gençliğini kıskanan bir kadındır. Arslanoğlu (2017, s. 254), Selim İleri’nin Firdevs Hanım’ı “ölümsüz dişiliğe tutkun bir kadın” olarak nitelendirdiğini aktarır.

\section{Matmazel De Courton}

Fransa'dan gelen Matmazel Courton, İstanbul'a ve Türk aile yapısına meraklıdır. Roman'da zaman zaman "ihtiyar kız" olarak da adlandırılır. Dört yaşından itibaren Nihal'in öğretmen ve dadılığını yapmaktadır. Çocuğu olmayan Matmazel Courton, ilk gördüğü andan itibaren Nihal ile anne kız ilişkisi kadar güçlü bir gönül bağı kurar. Asil, kibar, iyi niyetli, iffetli ve aile terbiyesi almış bir kadın olan Matmazel, gizliden gizliye Adnan Bey'e de aşıktır. Bihter ile yıldızı hiç barışmaz. Başta yasak aşk olmak üzere yalıdaki önemli olayların farkındadır ancak bunları bildiğini dışa vurmaz. Tek önemsediği Nihal'in eğitimi ve mutluluğudur. Olay ve kişiler arasında adeta dengeyi sağlamaktadır. Yalıdan ayrılmadan önce Nihal'in yanına giderek Behlül'den uzak durmasını salık verir.

\section{Nihal}

Adnan Bey'in yaklaşık on üç yaşındaki duygusal, kırılgan ve narin kızıdır. Küçük yaşta annesini kaybettiği için başta babası olmak üzere çevresindekiler adeta onun üzerine titremektedir. Babası ile birbirlerine çok düşkünlerdir. Nihal, Bihter'in yalıda en çok çekindiği kişidir. Bihter'in merkezde olduğu yasak aşk temasının dışında Nihal'in babasından uzaklaşması, sevdiklerinin ondan ayrılması ve Behlül ile evliği, Roman'ın en önemli olay örgülerindendir. Moran (1998, s. 59), bu bakış açısıyla Aşk-ı Memnu'yu, Nihal'in öyküsü olarak tanımlamanın olanaklı olduğunu belirtir.

Roman'da önce Nihal merkeze alınır. Adnan Bey ile Bihter'in evliliğine dair en çok merak edilen Nihal'in tepkisidir. Bu bile tek başına Nihal'in Roman'da ne denli önemli bir karakter olduğunu göstermektedir.

Nihal'in ön planda olduğu olay örgülerinde, zıtlıkların önemli bir anlatım aracı olarak kullanıldığ 1 görülür. Nihal'i mutsuz eden olayların çoğu, genellikle onun mutlu olduğu anlarda ortaya çıkmaktadır. Bu kontrast da duygu yoğunluğunu arttırmaktadır.

Nihal, Roman'da kadınlığın bütün evreleriyle karşımıza çıkmaktadır. Roman'ın başında babasının biricik kızı ve Bülend'in "annesi" konumundadır. Büyüyüp genç kız olduğunda ise Behlül'ün sevgilisi ve sonrasında da eși olur. Bu evrelerle ilgili olarak Moran (1998, s. 62), Nihal'in çocukluktan, genç kızlığa geçişinin adeta bir tören niteliğindeki "çarşaf giyme" sahnesiyle vurgulandığını ifade etmektedir.

Olay örgüsünün büyük bir bölümünde birbirleriyle mücadele eden Bihter ile Nihal'i ortak paydada buluşturan şey ise "sevilme" ihtiyacıdır. Zira bu ihtiyaç Bihter'i yasak aşka, Nihal'i ise Behlül ile evlenmeye sevk etmiştir.

Bunların dışında Roman'da yer verilen karakterler; Peyker, Nihat Bey, Şakire Hanım, Şayeste, Cemile, Süleyman Bey, Hacı Necip, Katina, Feridun ve Kette'dir. 


\section{Aşk-ı Memnu Romanında Öne Çıkan Hususlar}

Birçok eleştirmen Uşaklıgil'in en iyi yapıtının $A s ̧ k-\imath$ Memnu olduğunu belirtir (Moran, 1998, s. 52). Buna karşın yapıtın anafikri, meselesi ya da mesaj1 konusunda görüşler farklılaşmaktadır. Çoğu eleştirmen, merkezde Bihter'in ve yasak aşkın yer aldığını ifade etmektedir. Moran (1998, s. 52), Uşaklıgil üzerine yazılmış üç monografide ${ }^{1}$ de bu kanının savunulduğunu belirtir. Fethi Naci ise bu Roman'ın bir tezi olmadığını, başarısının da belki bu yaklaşımda olduğunu belirmektedir (Moran, 1998, s. 52). Aşk-ı Memnu farklı okumalara imkân verecek zengin bir romandır. Roman'ın odak noktasındaki karakter ve olayların zaman zaman değiştirilmesi, başka görüşlere ve farklı okumalara da imkân tanımaktadır. Roman'ın bir karakter ve bir mesele merkezinde değerlendirilmesinin, Roman'daki zengin mozaik yapının 1skalanmasına neden olacak indirgemeci bir yaklaşım olacağı değerlendirilmektedir.

Kantemir (2019, s. 227), Servet-i Fünun romanında toplumsal meselelere hiç yer verilmediğini, siyasî ve dinî baskıların devam ettiği bir dönemde, bu iki diktadan birine değinmeden toplumsal bir meseleyi anlatmanın güç olacağını ifade eder. Bu tespiti doğrularcasına Aşk-ı Meтnu'da da toplum yerine bireylerin ön planda olduğu görülür. Yazar, Roman'da toplumu doğrudan anlatamadığı için mekânı ağırlıklı olarak bir yalı, karakterleri ise bu yalıda yaşayan kişilerle sınırlar. Bu sınırlılıklar olay ve duyguların daha yoğun hissedilmesine olanak vermiştir. Çatışmalar, kişiler arasında olduğu kadar, kişilerin iç dünyalarında da yoğun olarak karşımıza çıkar. Bihter'in, kendi içinde yaşadığı sadakat ve aşk çatışması, bu konudaki örneklerden biridir. verilmiştir.

Yalının dışında nadiren de olsa Göksu, Kalender ve Beyoğlu gibi mekânlara da yer

Roman, Firdevs Hanım ve kızlarının çıktığı sandal gezisinin anlatılmasıyla başlar. Açııışın bu gezi ile yapılması ve sandaldaki "Melih Bey Takımı" ailesinin tasviri, gösteriş düşkünü bu ailenin özelliklerini imgesel olarak destekleyen bir yaklaşımdır. Sandal gezisinde Firdevs Hanım ile kızları arasında geçen konuşmalardan, anne ve kızlar arasında bazı sorunların olduğu anlaşılmaktadır. Olay örgüsünde çatışma ve gerilimin başladığı nokta olan Bihter'in, Adnan Bey'in evlenme teklifini kabul etmesinde; $\mathrm{Bu}$ sorunların önemli rol oynadığı, ilerleyen safhalarda görülecektir. Bihter, annesi gibi yaşam tarzı bakımından eleştirilen bir kadın olmamak, saygın ve refah bir yaşam sürmek hayaliyle bu teklifi kabul etmiştir.

Bunların yanında, farklı dünyalara ait iki ailenin bir evlilik etrafında bir araya gelmesi fikri de, Roman'a dinamizm ve yeni yan temalar doğurabilecek bir doğurganlık kazandırır. Bu iki aileden biri masum ve mutlu; diğeri huzursuz, günahkâr ve maddiyata düşü̈ndür. Bihter'le birlikte "Melih Bey Takımı", yalıya mutsuzluk ve huzursuzluğu bulaştıracak bir virüs gibi girmiştir.

Roman'daki ilk gerilim noktalarından biri, Şakire Hanım'ın Behlül'ü, Peyker ve Firdevs Hanım'ın yanında görerek kızmasıdır. Gördüklerine ve yaşadıklarına kızan Şakire Hanım, yalıdan ayrılabileceklerini ima ederken Bihter' in Adnan Bey'in başına büyük belalar açabileceğini de ifade eder. Bu sözler gelecekte olacakların habercisi niteliğindedir.

Bihter'in yasak aşka, Nihal'in ise yalnızlığa sürüklenişinden oluşan iki olay örgüsü Roman'ın iskeletini oluşturmaktadır. Bu noktadan hareketle, kadınların Roman'da güçlü olduğu söylenebilir. Esaslı mücadeleler kadınlar arasında geçmekte, önemli olayların vuku bulmasını kadınlar tetiklemektedir. Nihal ile Behlül'ün evlenme fikrinin, Firdevs Hanım'dan çıkması; Bülend, Matmazel ve çalışanların Bihter tarafından evden gönderilmesi, en büyük mücadelenin Bihter ile Nihal arasında geçmesi bu konudaki önemli örneklerdendir.

\footnotetext{
${ }^{1}$ Bu monografiler şunlardır: L. Sami Akalın'ın Halit Ziya Uşaklıgil Hayatı Sanatı Eserleri, Cemil Yener'in Halit Ziya Uşaklıgil ve Olcay Önertoy'un Halit Ziya Uşaklıgil Romancılı̆̆ ve Romanımızdaki Yeri.
} 
Moran (1998, s. 63) Aşk-ı Memnu'da kişiler arasındaki duygusal yaklaşma ve uzaklaşmanın baleyi andırdığını söylemektedir. Gerçekten de yaklaşma ve uzaklaşma olgusu özellikle Bihter ile Behlül, Adnan Bey ile Nihal'in ilişsklilerinde net olarak görülmektedir.

İkili ilişkiler dışında önemli bir olgu da "iki kişi arasında kalma durumu"dur. Adnan Bey, kızı Nihal ile Bihter arasında; Nihal, babası ile Bihter arasında; Bihter, Adnan Bey ile Behlül arasında; Behlül ise Nihal ile Bihter arasında bocalamaktadır.

Roman'ın yapısal kurgusunda dikkat çeken temalardan biri de "ayrıllk"tır. Nihal'in yakınlık duyduğu Matmazel, Bülend ve yalı çalışanlarının yalıdan ayrılışı; bu önemli temaya verilecek örneklerden biridir.

Yapıtta yalnızca sıkıntı ve mücadeleler yoktur. Gerilimlerin çözülebilmesi için insanın içini 1sıtan, samimi ve temiz duygulara da yer verimiştir. Adnan Bey'in iyi niyetli kişiliği, Nihal'in çocuksu saflığı, Beşir'in içtenlik ve doğruluğu bu bağlamda değerlendirilebilir.

Olay örgüsünde dikkat çeken hususlardan biri de kişilerin özellikleri ile olaylar arasındaki uyumdur. Örneğin Behlül için hayattaki en önemli şey eğlencedir. Hatta onun için önemli olan eğlenmek değil eğleniyor görünmektir. Bu özellikleriyle yasak aşkın maceracı zevkine kendini kolayca kaptırması şaşırtıcı olmaz. Yaşadığı yasak aşk ortaya çıktığında da, yaptığının arkasında durmaktan ya da bedel ödemekten kaçar. Bihter ise sevilmeye olan ihtiyacı nedeniyle Behlül'e gönlünü kaptırır. Matmazel Courton, sevgiye ve ilgiye muhtaç olduğu için Nihal ile bir empati kurmuş ve onun mürebbiyeliğini kabul etmiştir.

Batı'lı tarzda yaşayan bir ailenin yaşamını konu alan bu Roman'da, ailenin yapısıyla uyumlu olarak Batı sanatıyla ilgili dikkat çekici bilgi ve konulara rastlanır. Özellikle Nihal'i konu alan satırlarda bu husus daha çok görülür. Roman'da yer alan sanatçı, yazar ve eserlerin bazıları şunlardır: Carl Czerny'nin (1791-1857) piyano alıştırmaları (Uşaklıgil, 2000, s. 84, 113), Muzio Clementi'nin (1752-1832) sonat ve piyano etütleri (Uşaklıgil, 2000, s. 84), Johann Strauss'un (1825-1899) valsleri (Ușaklıgil, 2000, s. 84, 249), Olivier Metra'nın (1830-1899) quadrilleri (Uşaklıgil, 2000, s. 84, 249), Frederic Chopin'in (1810-1849) noktürnleri (Uşaklıgil, 2000, s. 84, 250), Robert Schumann'ın (1810-1856) liedleri (Uşaklıgil, 2000, s. 84, 250), İtalyan opera bestecileri Domenico Cimarosa (1749-1801), Gaetano Donizetti (1797-1848), Saverio Mercadante (1795-1870), Gioacchino Rossini (1792-1868), Rus piyanist Anton Rubinstein (1829-1894) (Uşaklıgil, 2000, s. 84), Alman besteci Richard Wagner (1813-1883) (Uşaklıgil, 2000, s. 85) ve Fransız yazar Alexandre Dumas (1824-1895) (Uşaklıgil, 2000, s. 88).

Nihal'in yanı sıra Behlül'ün de tiyatro sevgisinden bahsedilir. Behlül, Bihter'e sakladığı bazı kadın resimleri ile ilgili açıklma yaparken "Bilseniz tiyatro kıyafetlerine ne kadar merakım vardır. Bunlar bu yaz size o kadar bahsettiğim İtalyan Operet kumpanyasının kadınları...Sırf elbiselerin tuhaflığı için alınmış şeyler” demektedir (Uşaklıgil, 2000, s. 194).

Adnan Bey ve ailesine karşın Melih Bey Takımının alaturka olarak nitelendirilebilecek kültür hayatına dair ipuçları da verilmektedir. Örneğin misafir olarak gittikleri bir düğünde Peyker piyano, Bihter ud, Naciye Hanım ise kanun ile Civan A ğa'nın nihavent makamında bestelediği "Dil Seni Sevmeyende Lezzet mi Olur?" adlı şarkıyı seslendirirler. Ardından Suzinak makamında bir fasıl yapılır ve Bihter, Hacı Arif Bey'in "Çekme Elem ü Derdini Bu Dehr-i Fenanın” şarkısını söyler.

Uşaklıgil, alaturka ve alafranga olarak nitelendirilebilecek kültürlerle sınırlı kalmaz. Olay örgüsünün bir ayağı İstanbul'dayken diğer ayağı bazen Hindistana kadar uzanır. Hinduizmde dünyanın koruyucusu olduğuna inanılan tanrı Vişnu'nun heykeline yer vermesi bu yaklaşıma örnek olarak gösterilebilir (Uşaklıgil, 2000, s. 202). 
1939 yılında yeni harflerle ilk baskısında, Arapça ve Farsça kelimelerin yazar tarafından Türkçeleştirilmesine rağmen Roman'da Osmanlıcanın ağdalı ve ağır üslubu göze çarpmaktadır. Bunu yanında uzun tasvir ve benzetmeler, anlatıma hacim katarak yazı dilini zenginleştirmektedir.

Romanın sonunda Bihter'in ölümü ve Behlül'ün kaçmasıyla birlikte çatışmalar, gerginlikler ve sorunlar sona erer. Adnan Bey ve ailesi tekrar mutlu ve huzurlu günlerine dönerler. Adnan Bey ile ailesi açısından Roman'ın kurgusunda bir A-B-A formundan söz edilebilir.

\section{Roman ve Opera Arasındaki Farklar}

Roman ve opera gibi iki farklı türde, aynı konunun yeniden yazımlarında, bazı konuların çıkartılması ya da eklenmesi gibi değişikliklerin yapılması doğaldır. Bu bağlamda Opera'da da bazı farklılıklar göze çarpmaktadır. İlk göze çarpan farklılık, Roman'da görülen tasvir ve düşünceleri yansıtan metinlerin, Operada diyaloglar şeklinde özetlenerek sunulmasıdır. Tarık Günersel'in yazdığı librettoda, dönemi gereği Halit Ziya Uşaklıgil'in değinemediği toplumsal ve politik konulara değinildiği görülür. Her ne kadar Halit Ziya Uşaklıgil, toplumsal ve politik konulara değinmese de Günersel bu yaklaşımın dahi politik olduğunu düşünür ve şunları ifade eder: "Romanda siyasetten söz edilmediği ileri sürülebilir; ama Hâlid Ziya'nın siyasal eleştirisi romanda siyasetin hiç olmamasında var zaten. 1899-1900 yıllarındaki baskı ortamında, Munch'un tablosundaki çı̆̆lık gibi bir çığlık bu roman: Sessiz, sarsıcı." (Şahin, 2010, s. 124-125).

Opera'daki karakterler; Bihter, Firdevs Hanım, Adnan Bey, Behlül, Beşir, İmam, Nihal, Nesrin, Mlle-De Courton, Dondurmacı, Bozacı, Laternacı, I. Hafiye, II. Hafiye ve Kette'dir.

Roman'da Batı'lı bir tarzda yaşayan Adnan Bey ve ailesinin, Opera'da muhafazakâr bir hayat sürmesi, iki tür arasındaki en dikkat çekici farklılıktır. Bu konuda librettist şunları ifade etmektedir: "İslamiyet bu toplumun kültürünün bir parçasıdır. Nasıl Batı operalarında Hıristiyanlık unsurları varsa, İslam unsurları da bizim operamızda olabilir, olmalı" (Yazıcı \& Gökbudak, 2015, s. 593).

Roman'da genelde Nihal özelinde gördügüumüz Batı sanatı olgusuna karşın, Opera'nın Dede Efendi'nin Yine Bir Gülnihal adlı eseri ile başlaması da Doğu-Batı karşıtlığı yaklaşımının bir örneğidir.

Şahin (2010, s. 125-128), Tarık Günersel'in Aşk-ı Метnu romanından hareketle yazdığı tiyatro oyunuyla ilgili olarak, Roman'ın Melih Bey Takımı'nın hayatından yola çıkılarak, Tiyatro'nun ise baba-kız ilişkisi ekseninde kurulduğunu belirtir (Şahin, 2010, s. 125-128). Benzer bir şekilde, Roman'ın başında Melih Bey Takımı'nın Boğaz'da yaptığı sandal gezisine Opera'da yer verilmediği, bunun yerine Opera'nın doğrudan Adnan Bey ile Bihter'in düğünüyle başladığı görülür. Bu bağlamda Roman'daki sandal gezisinde Melih Bey Takımı hakkında verilen bilgiler de doğal olarak Opera'da yer almaz.

Roman'da yer almamasına karşın Opera'da, Bihter ile Adnan Bey'in nikâhını bir imam kıymaktadır. Bu husus da librettistin Doğu perspektifli yaklaşımıyla uyumludur. İmam, nikâhı k1yarken İslamiyete uygun bir terminoloji kullanmaktadır. "İmam Nikâhı" temasını besteci Selman Ada'nın eklemek istediğini belirten Librettist, bu konuda şunları söyler: "İslamiyet bu toplumun kültürünün bir parçasıdır. Nasıl Batı operalarında Hıristiyanlık unsurları varsa, İslam unsurları da bizim operamızda olabilir, olmal1." (Yazıc1 \& Gökbudak, 2015, s. 593).

Yazıcı ve Gökbudak (2015, s. 593), hem mevsim geçişlerini vurgulamak, hem de "kültürel" bir unsur eklemek için hikâyenin akışına "boza" ve "dondurma" satışının eklendiğini librettisten aktarmaktadır.

Evlenme töreninde Adnan Bey'in şahidi olan Halid Ziya ile Roman yazarının aynı adı taşıması ince bir göndermedir. 
Opera'da Adnan Bey ile Bihter'in evlenme töreninden hemen sonra, Roman'da yer almayan fotoğrafçı Karnik Usta, gelin ve damadın fotoğraflarını çeker.

Halid Ziya Uşaklıgil'in Aşk-ı Memnu'da, döneminin ruhu nedeniyle baskıcı yönetimden ve dolayısıyla toplumdan bahsetmekten kaçındığı görülür. Ancak Opera'da bu durum tam tersi bir yaklaşımla ele alınır. Baskıcı yönetim açık açık vurgulanır. Toplumsal ve politik konuların açıkça hatta vurgulanarak yansıtılması, Roman ile Opera arasındaki en önemli farkl111klardan biridir. Opera'da evlenme merasimi biter bitmez Adnan Bey, hafiyeler tarafından "okumak" suçlamasıyla tutuklanır. Bu sahne librettoda şu sözlerle yansıtılır: "Bu şiir ne arıyor bur'da? Yasak! Ciddi bir suç okumak!" (Kanan, 2007, s. 60).

Yine Adnan Bey'in Hürriyet Aryası'ndaki şu sözleri de aynı minvalde değerlendirilebilir:

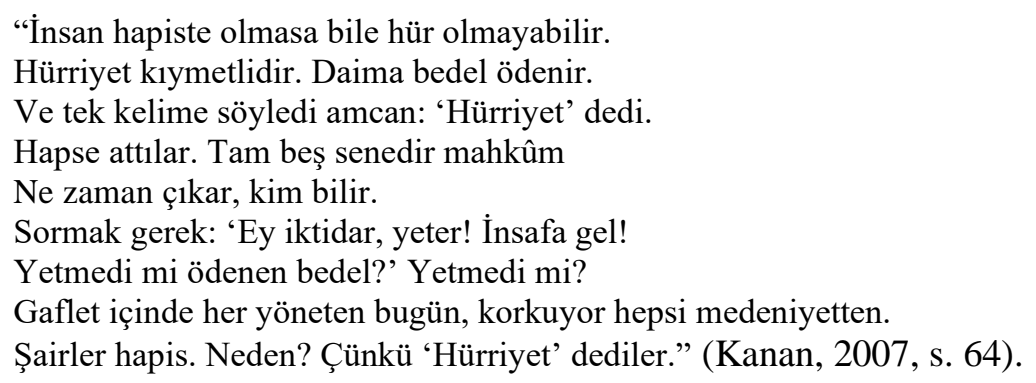

Politik eleştiri konusuna bir başka örnek olarak Adnan Bey'in tutuklanmasının hemen ardından librettodaki şu sözleri gösterilebilir: "İstibdat bu! [...] Hürriyet yok! [...] Jurnalci iși bu!.” (Kanan, 2007, s. 61). Nihal de bu duruma üzülerek, babasına Bihter'in nazarının değdiğini ifade eder.

Opera'da, Firdevs Hanım Behlül'e "Benden duymuş olmayın ama, sizi çok beğenen genç ve güzel bir kadın var burada. Kızım Bihter" (Kanan, 2007, s. 60) diyerek Behlül'ün beynine yasak aşkın ilk virüsünü atmış olur. Bu husus Roman'da yer almamaktadır.

Roman'da yer almayan ancak Opera'da görülen bir başka konu da Adnan Bey’in, tutuklanmasının hemen ardından Nihal'e amcasından hatıra olan bir tabancayı, namusunu korumas1 için vermesidir. Bu tabancanın varlığını bilenler ise yasak aşkı yaşayan Behlül ve Bihter'dir. Bu çelişki, anlamlı ve dikkat çekicidir.

Birinci Perde Dördüncü Sahne'deki Nihal’in şu sözleri, Bihter'i bekleyen trajik sonun ilk sinyali gibidir:

"Nihal: İnsan niye intihar eder?

Mlle de Courton: Ümidi kalmayınca sars1lır." (Kanan, 2007, s. 68).

Opera'da, maske önemli bir anlatım aracı olarak karşımıza çıkmaktadır. Örneğin Birinci Perde Dördüncü Sahne'de Adnan Bey, Behlül maskesi takar. Bihter'in hayatındaki iki önemli erkeğin yüzü, tek bir vücutta maske yardımıyla sunulmaktadır. Sahne sanatlarında maske, izleyici ile oyuncu arasında bir perde işlevi görür. Maske, tarih boyunca farklı amaçlarla kullanılmakla birlikte, temelde takanın kimliğini gizleyen bir aksesuardır. Burada Adnan Bey'in kimliğinin, yasak aşkın taraflarından biri olan Behlül'ün maskesi ile gizlenmesi, çok katmanlı okumalara olanak verecek bilinçli bir tercihtir. Opera'da Behlül de kimi zaman Casanova maskesi takmaktadır. Adnan Bey’in maskeler ile ilgili şu sözleri dikkat çekicidir:

"Maskeler yetişir imdada bitince kudret-i idrak [...]

Maskeler yetişir imdada. Kaybolur sarsan hakikat" (Kanan, 2007, s. 85).

Librettoda kimi zaman olay örgüsüyle hiç bir bağı olmayan, sürrealizme yaklaşan ifadelere rastlanır. Örneğin bazı diyaloglarda bonbon şekeri konu edilir. 
"Behlül: Hayattan tad almayı öğrenin biraz.

Bonbon iyi gelir, buy'run.” (Kanan, 2007, s. 70).

"Bihter [Nihal'in ilk çarşafını alması üzerine] "Şerefine bonbon da almıştım" (Kanan, 2007, s. 66).

Opera'da Bihter, Adnan Bey'e "Mademoiselle metresinizmiş" diyerek Matmazel'in evden gönderilmesini ister. Roman'da böyle bir konu yer almamaktadır.

Firdevs Hanım, Roman'da Adnan Bey ile evlenme arzusunu dişa vurmaz. Okuyucu bu sonucu çıkarır. Opera'da ise Firdevs Hanım, Adnan Bey'e olan hislerini açıç̧a söylemekle kalmaz, Bihter'in Behlül'e yakıştığı konusunda dedikoduların varlığından söz ederek Adnan Bey'in Bihter'den vazgeçerek kendisiyle evlenmesini ister (Kanan, 2007, s. 79, 80).

İkinci Perde Dördüncü Sahne'de, Firdevs Hanım'ın, kantosunda söylediği şu sözler, Adnan Bey'den vazgeçmediğini göstermektedir:

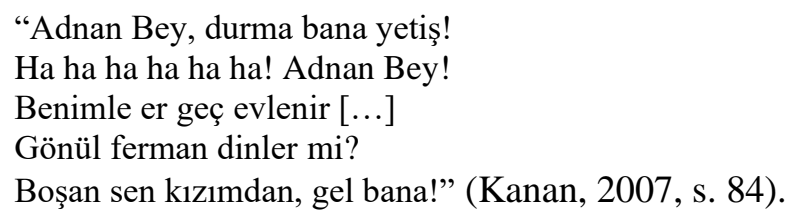

Roman'dan farklı olarak Opera'da Bihter, annesi Firdevs Hanım'a hamile olduğunu söyler. Bu eklemenin nedenini Ada şöyle ifade etmektedir:

"Modern dünyanın büyük kentlerinde buna benzer hadiseler yaşandığında intihar çok inandırıcı bir sonuç olarak karşımıza çıkmıyor [...] Bihter'in intihara uzanan hayal kırıklığını bu anahtar cümleyle inandırıcı kılmaya çalıştık operada" (Kanan, 2007, s. 28).

Roman'da Nihal'in evlenmek gibi bir arzusu yoktur. Opera'da ise İkinci Perde Dördüncü Sahne'deki şu sözler Nihal'in evlenme arzusunu göstermektedir:

"Tek arzum gelinlik giymek!

Tatlı bir kocaya düşmek!

Yakışıklı biri olsun!

Aşk bahçem dolsun!" (Kanan, 2007, s. 80).

Opera'da, Bihter'e beslediği sevginin karşı1lısız olması nedeniyle Adnan Bey'in üzüntüsünü yansıtan şu cümlesi oldukça etkileyicidir: "İnsan suretinde saklanan keskin hançerim. Cehennemmiş bu sevda. Zifiri bir hasretim" (Kanan, 2007, s. 85).

Maske, Opera'nın sonunda da önemli bir anlatım aracı olarak kullanılmaktadır. Koro, yapıtın sonunda maskelerini çıkararak şu son sözleri söyler:

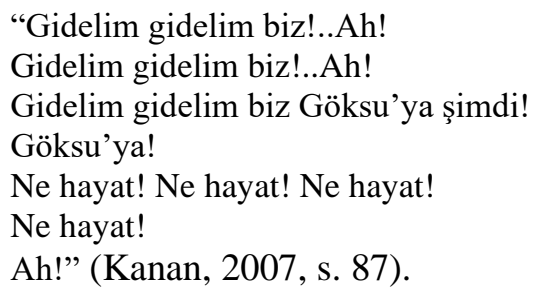

Opera'da Bülent, Peyker, Nihat Bey, Şakire Hanım, Şayeste, Cemile, Süleyman Bey, Hacı Necip ve Katina karakterlerine hiç yer verilmemiştir. Dolayısıyla bu karakterlerin ön planda olduğu olaylar da Opera'da yer almaktadır. Behlül'ün Bihter'den önce Peyker'in peşinde koşarak onu elde etmeye çalışması, bu konuya örnek olarak gösterilebilir. 


\section{Operanın Müziği}

1965 yılında 6660 sayılı "Harika Çocuk Yasası" kapsamında devlet tarafından Paris Ulusal Yüksek Konservatuvarına eğitim için gönderilen Selman Ada, Aşk-ı Memnu operasında çok iyi bildiği Batı müziği malzemeleri ile yaşadığı coğrafyanın müzikal malzemelerini ortak paydada ustaca birleştirerek, güzel ve değerli bir operayı ülkemiz repertuvarına kazandırmıştır.

Aşk-ı Memnu'da olay örgüsü ile uyumlu bir şekilde ilerleyen, dramayı ve duyguları destekleyen bir müzikal yaklaşımın gözetildiği söylenebilir.

Ada, Aşk-ı Memnu'nun müzikal tasarım ve yaratım aşamalarında hangi düşüncelerle hareket ettiğini şu sözlerle ifade etmektedir:

"Müzikte yaptığım şey dramı tamamen desteklemek oldu. Dünyaya klasik bir 'Türk Operası' kazandırmaya amaçladım. Aryaları, düetleri akılda kalan, Türk ve yabancı operasevelerin mırıldanabileceği, her zaman konservatuvarlarda, konserlerde ve şan resitallerinde her ülkede seslendirilecek olan" (Kanan, 2007, s. 28).

Opera, Dede Efendi'nin Rast Semai Yine Bir Gülnihal adlı eseri ile başlar. Ezgiye eşlik eden flüt, obua ve klarnetlerdeki salkım akorlar, tonal yapıyı adeta soyutlamaktadır. Ezgi, koro tarafindan seslendirilir.

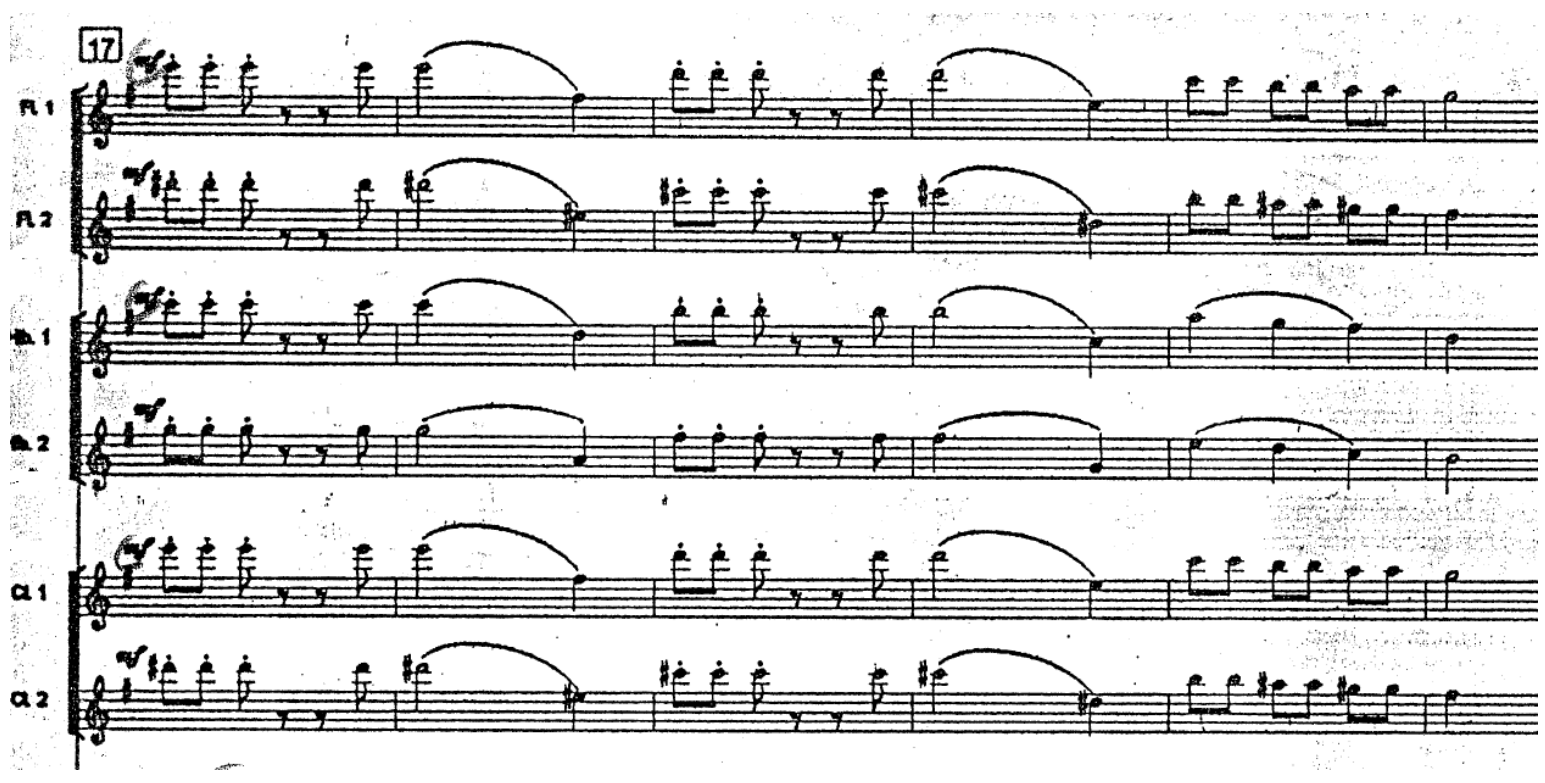

Nota 1: Yine Bir Gülnihal adlı eserin 17-21. ölçülerinde flüt, obua ve klarnet partisindeki eşlik.

Ardından geleneksel Türk müziğinde de sıklıkla görülen 9/8'lik aksak tartımlı ölçü birimi (yer yer 7/8'lik) üzerinde, onaltılık notalardan oluşan neșeli ve dinamik bir eşlikle, Firdevs Hanım ve Bihter'in diyalogları sunulur. Eşlikte la kararlı armonik minör ve Nev'eser makamı dizi sesleri birlikte kullanılmıştır. Bu eşlikte, vurmalı çalgılar arasında zilli defin kullanımı da dikkat çekicidir. 


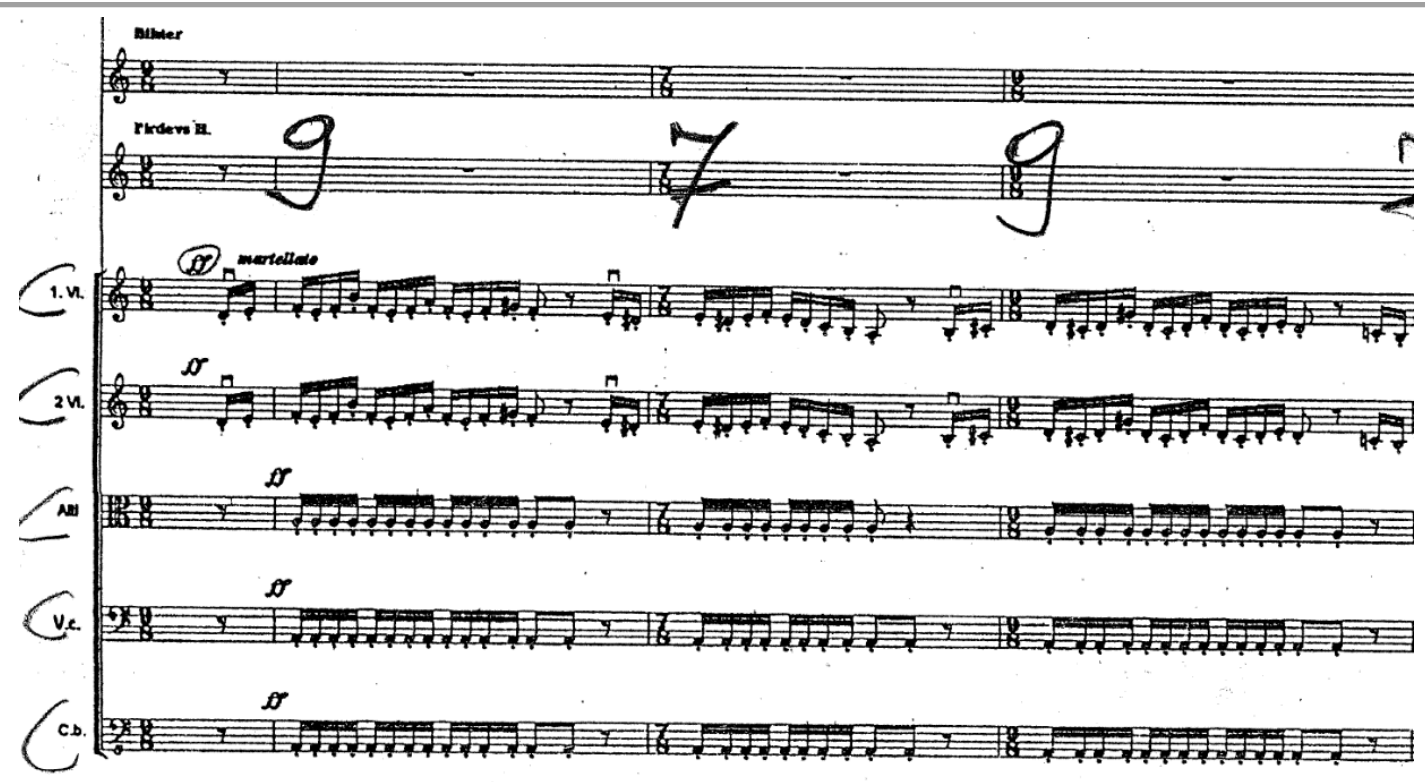

Nota 2: Yaylı çalgılar partisinde Firdevs Hanım ve Bihter'in diyaloglarını destekleyen eşlik.

$\mathrm{Bu}$ ezgisel eşliğin hemen ardından Fa\# kararlı Segâh makamı dizi seslerinin kullanıldığı Segâh Evlenme Ayini başlar. İlk olarak viyolonselin sunduğu ezgiye kudüm, semai usulünde eşlik eder.

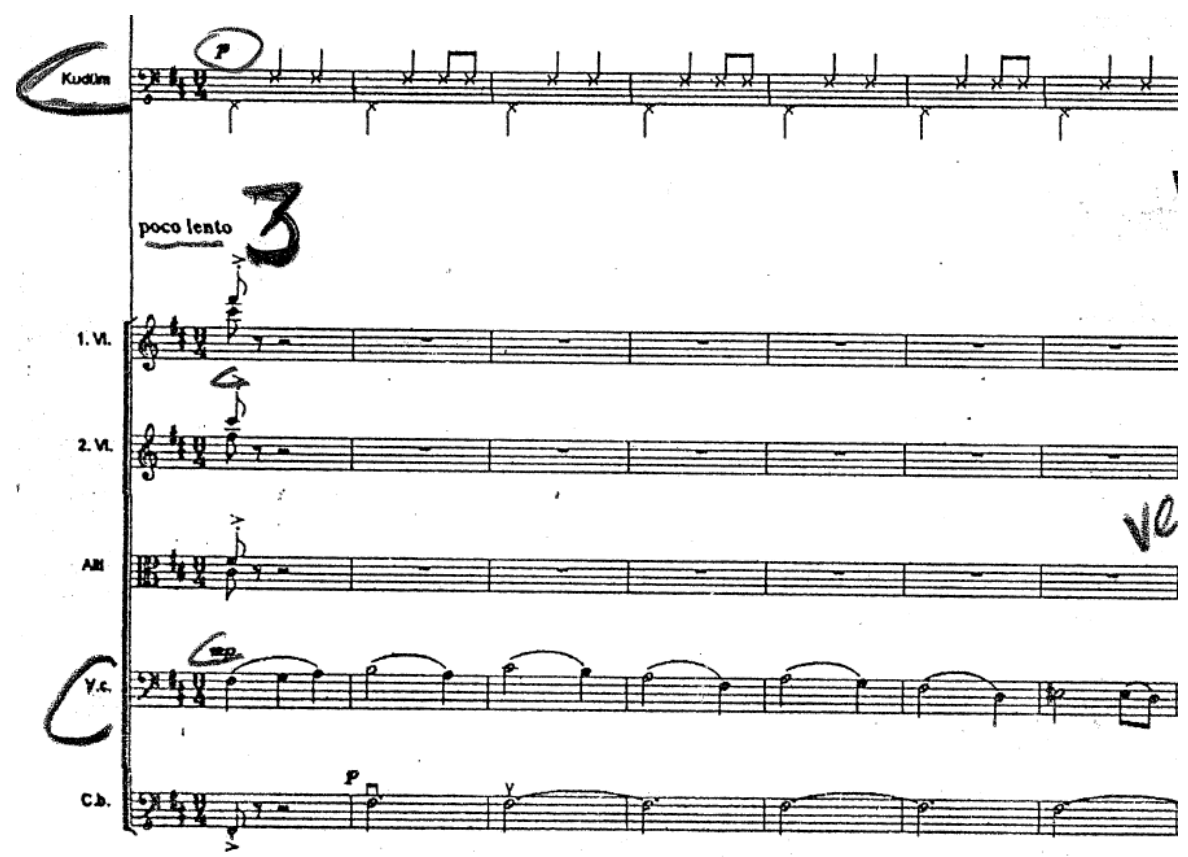

Nota 3: Segâh Evlenme Ayini'nin ilk 7 ölçüsü.

Segâh Evlenme Ayini’nin 40. ölçüsünde, kudüm “düyek” usulü ile reçitatife eşlik eder. 


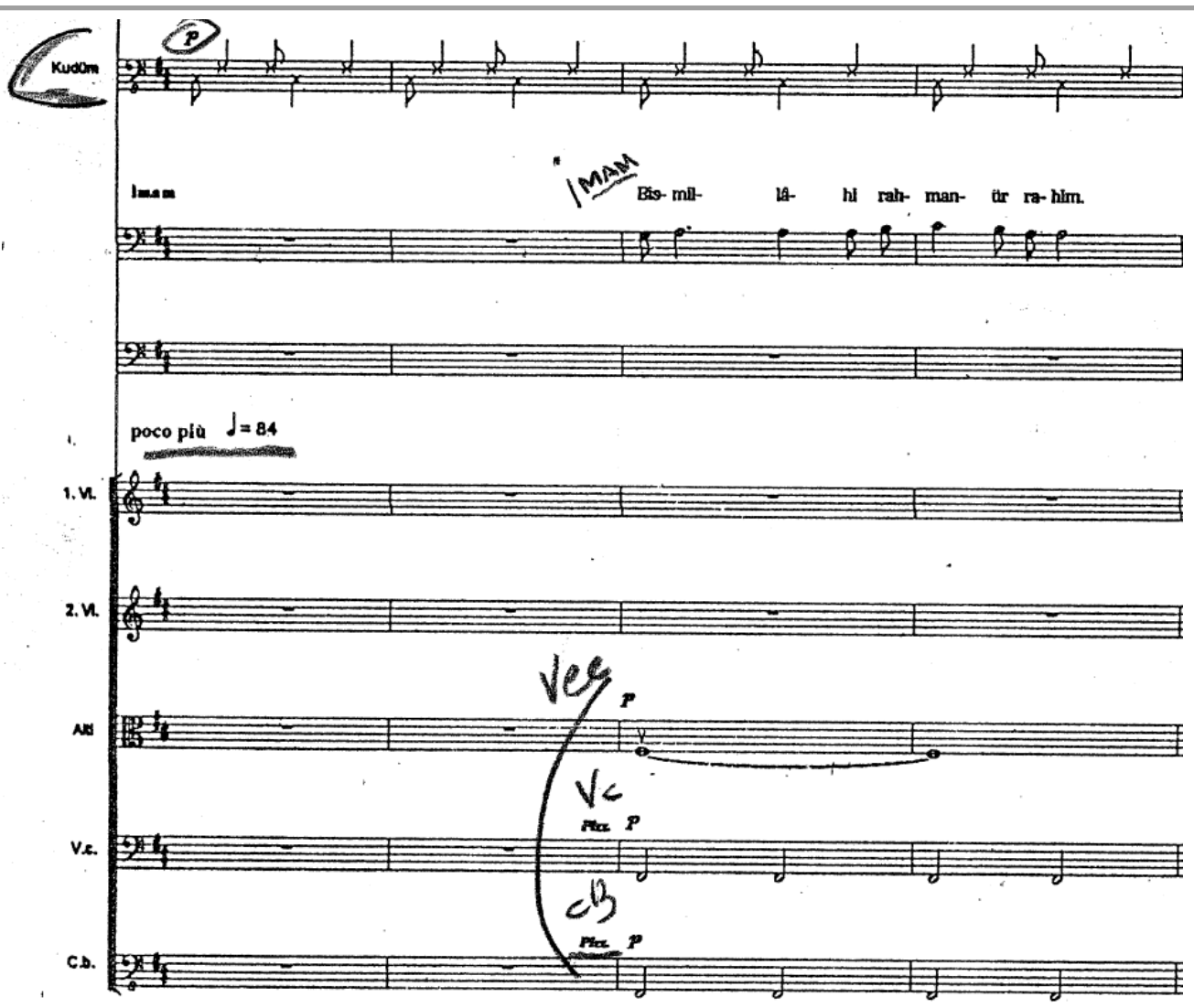

Nota 4: Segâh Evlenme Ayini'nin 40-43. ölçülerinde yer alan yaylı çalgılar, vokal ve kudüm partileri.

Segâh Evlenme Ayini'ninden sonra saydam ve hafif bir eşlik üzerinde koro (Davetliler Korosu), bu evliliğe dair düşünceleri ağır ve esrarengiz bir müzikal atmosferle ifade eder. Koro partisindeki makamsal nitelikli ezgisel çizgiyi destekleyen armonik yapıda, dörtlü ve ikili aralıkların hâkim olduğu görülmektedir. 


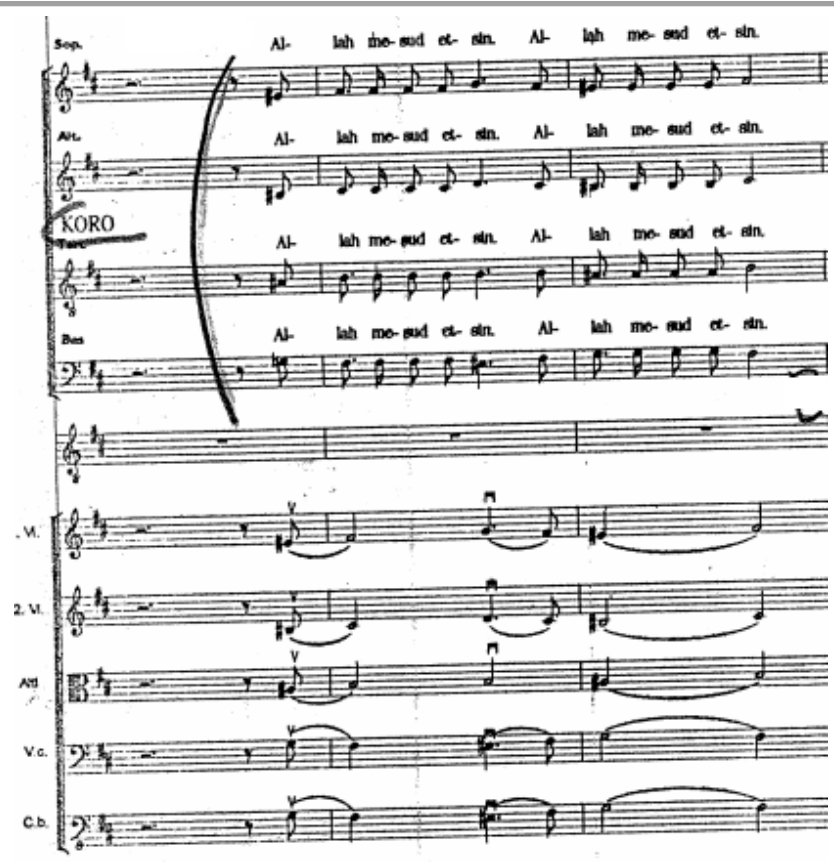

Nota 5: Davetliler Korosu'nun ilk üç ölçüsündeki yaylı çalgılar ve koro partisi.

Birinci Perde'nin "Bekleyiş ve Hürriyet" adlı İkinci Sahne'si, Nihal, Beşir ve Adnan Bey'in yer aldığ 1 recitativo ile başlar. Recitativo'nun başında kontrbas, viyolonsel ve tuba, Hüzzam makamı dizi sesleri ile birinci fikri; flüt, keman ve viyolalar ise tremolo akorlardan oluşan ikinci fikri seslendirirler.

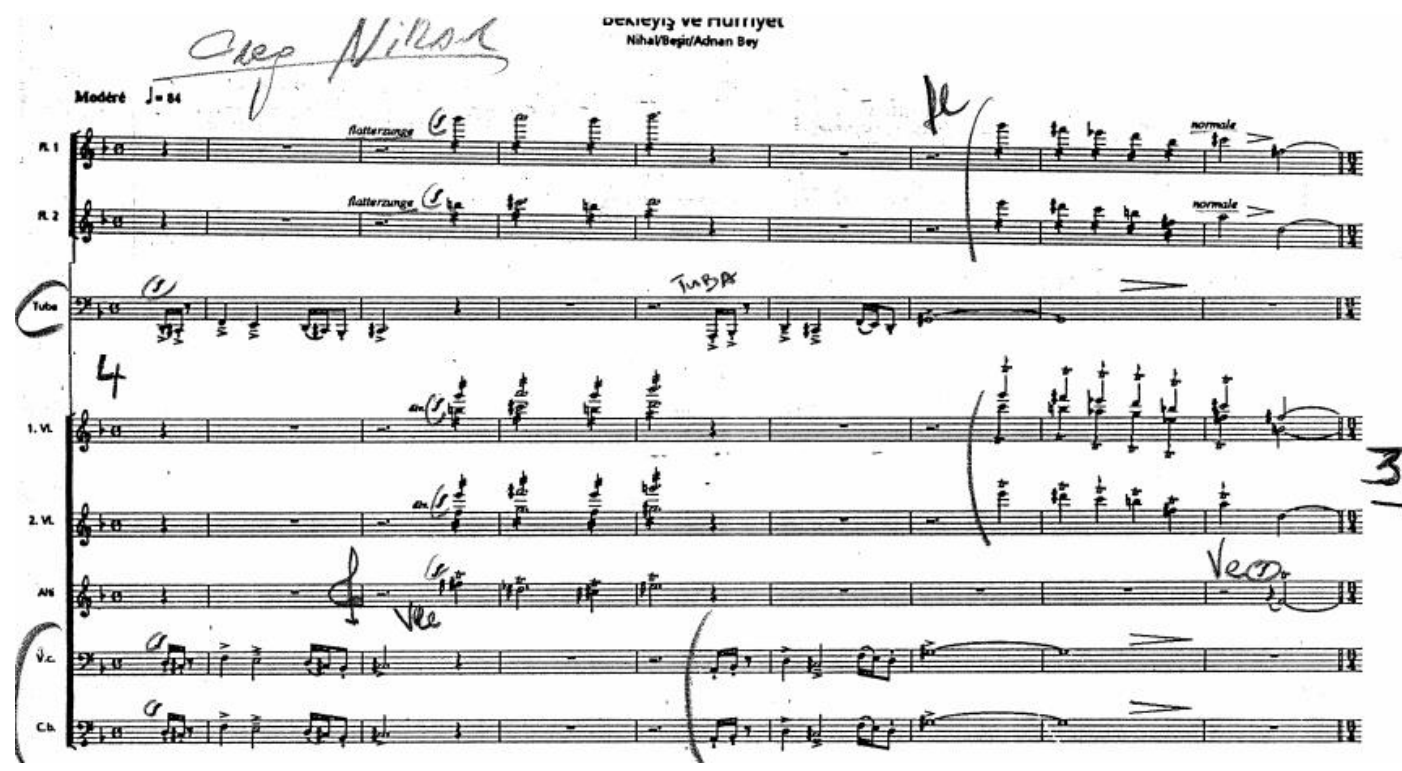

Nota 6: Birinci Perde İkinci Sahne'nin başlangıcı.

Çarşaf Ritüeli'nin yapıldığı Birinci Perde Üçüncü Sahne, Bihter ve Nihal'in seslendirdikleri recitativo ile başlar. Recitativo'nun girişinde klarnet, fagot, viyolonsel ve kontrbas partilerinin duyurduğu onaltılık üçlemelerin üzerinde; korno, keman ve viyolanın selendirdiği uzun sesli iki ölçülük cümle parçacığ işitilmektedir. 


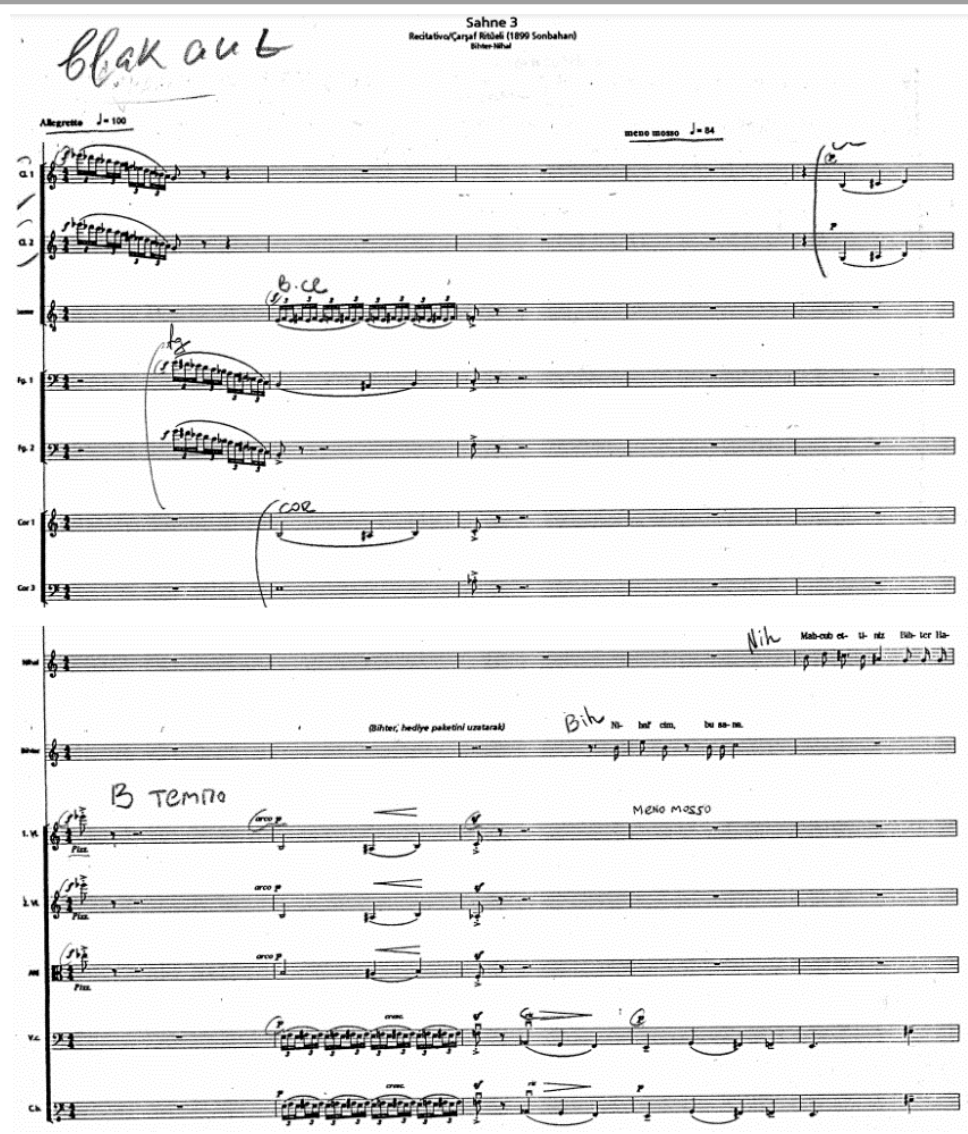

Nota 7: Birinci Perde Üçüncü Sahne'nin ilk ölçüleri.

"Fransızca Şan Dersi” konulu Birinci Perde Dördüncü Sahne, Mlle.de Courton, Nihal ve Adnan Bey'in seslendirdiği re minör tonundaki Double Duo ile başlamaktadır. Double Duo'nun girişinde I. fagot, arp ve viyolonsel ezgiyi seslendirirken; viyolonsel ve kontrbas bas çizgisiyle bu ezgiye eşlik etmektedir.

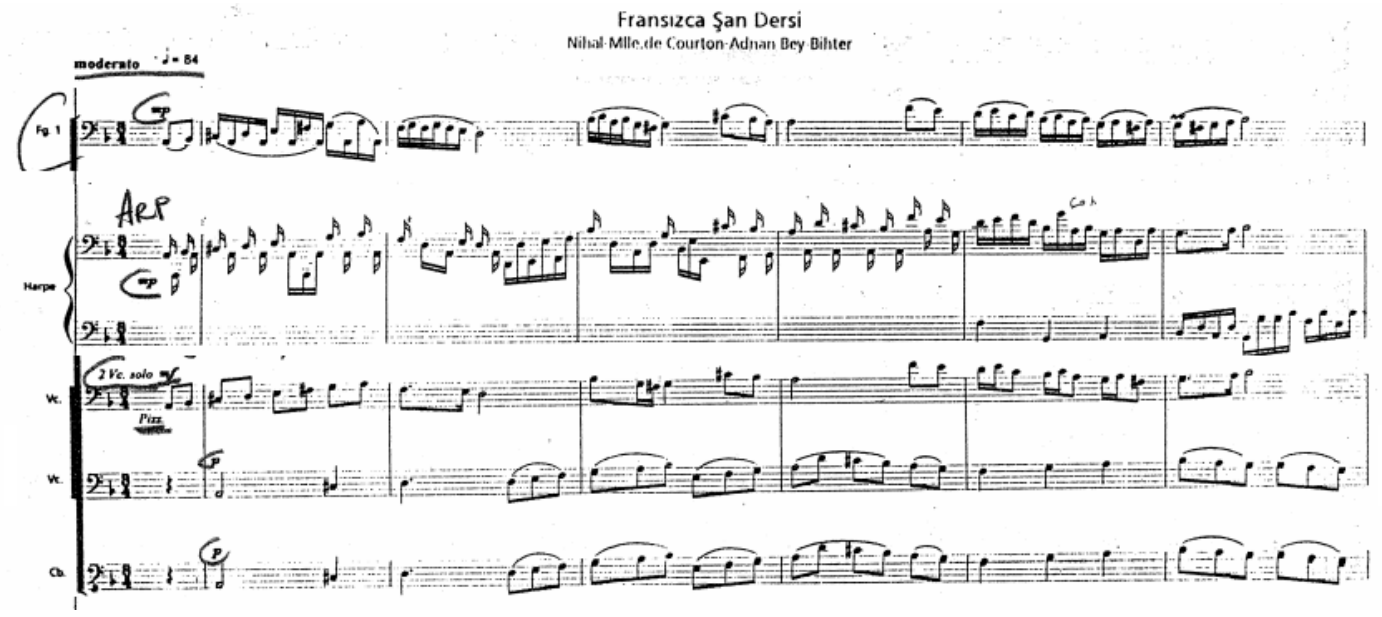

Nota 8: Birinci Perde Dördüncü Sahne'nin girişi.

İkinci Perde'nin “Aşk Düeti ve Evlenme Sene-i Devriyesi” adlı Birinci Sahne’si, Bihter ve Behlül'ün Aşk Düeti ile başlamaktadır. Aşk Düeti, 4/4'lük ölçü biriminde, do\# minör tonunda, kuvvetli zamanlarda viyolonsel ve kontrbasların pizzicato sekizlikliklerinin, hafif zamanlarda ise 
viyolaların senkoplu dörtlüklerinin öne çıktığı örgü üzerinde; I. kemanların geniş bir ses alanına yayılan eşlik çizgisini duyurmasıyla başlar.

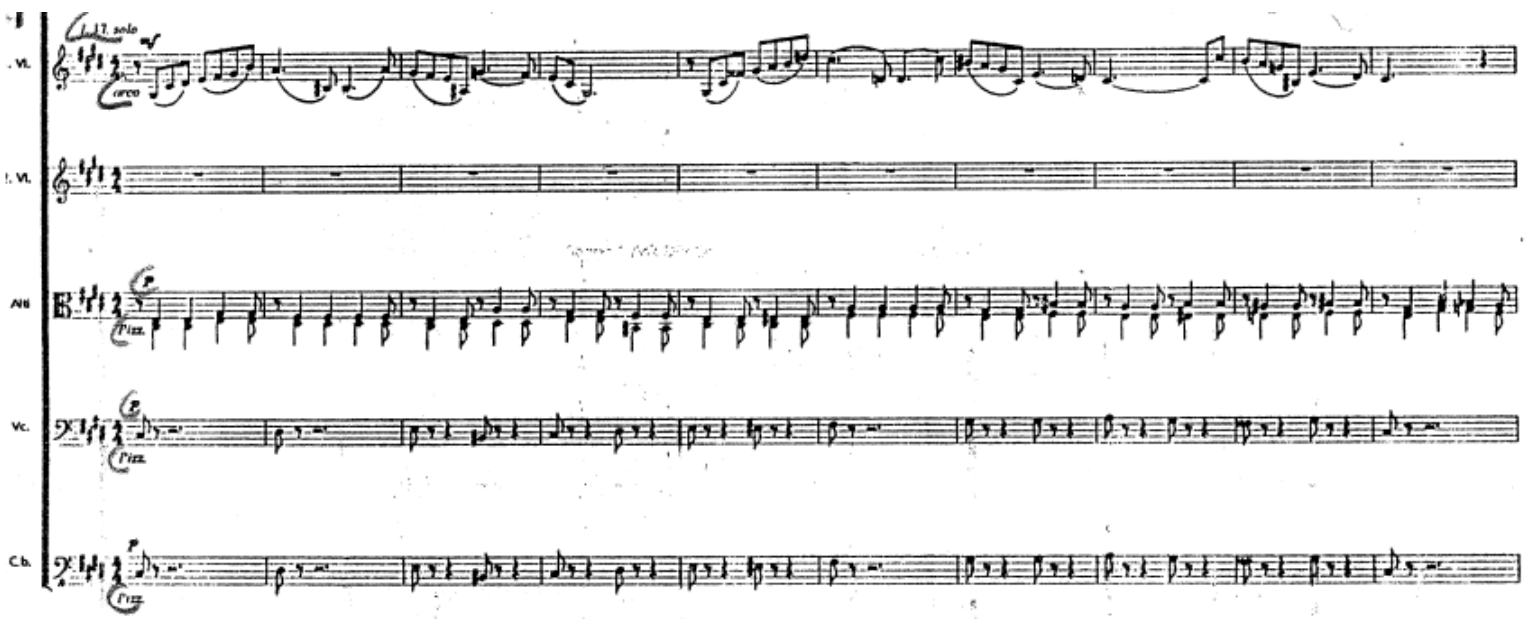

Nota 9: İkinci Perde Birinci Sahne'nin 1-10. ölçüleri.

"Bihter'in Serzenişi ve Mlle de Courton'un Kovulması" başlıklı İkinci Perde İkinci Sahne; Bihter, Behlül, Adnan Bey, Mlle.de Courton ve Nesrin'in seslendirdiği Recitativo ile başlar. Recitativo'nun başında si bemol kararlı Nev'eser makamı dizi seslerinin işlendiği görülür. Birer ölçülük do ve sib eksenli akorlar; tahta üflemeli enstrümanlar, trombonlar, tuba, timpani, arp ve yaylılar (viyolonsel hariç) tarafından duyurulurken; viyolonseller birinci ve üçüncü ölçülerin son vuruşunda otuzikilik süre değerleri ile Nev'eser makamı dizi seslerini yanaşı olarak seslendirir. Beşinci ölçüden başlayarak $0,4,6,9^{2}$ ses aralıklarından oluşan akorlar; viyolonsel, viyola ve kornolar marifetiyle örgüye katılır.

\footnotetext{
${ }^{2} 0$ 'dan başlayarak her sayı artışı bir yarım ses tizleştirmeye karşılık gelir. Örneğin kök sesi do olan 0,4,6,9 aralıklarından oluşan akor do-mi-fa\#-la\# olacaktır.
} 


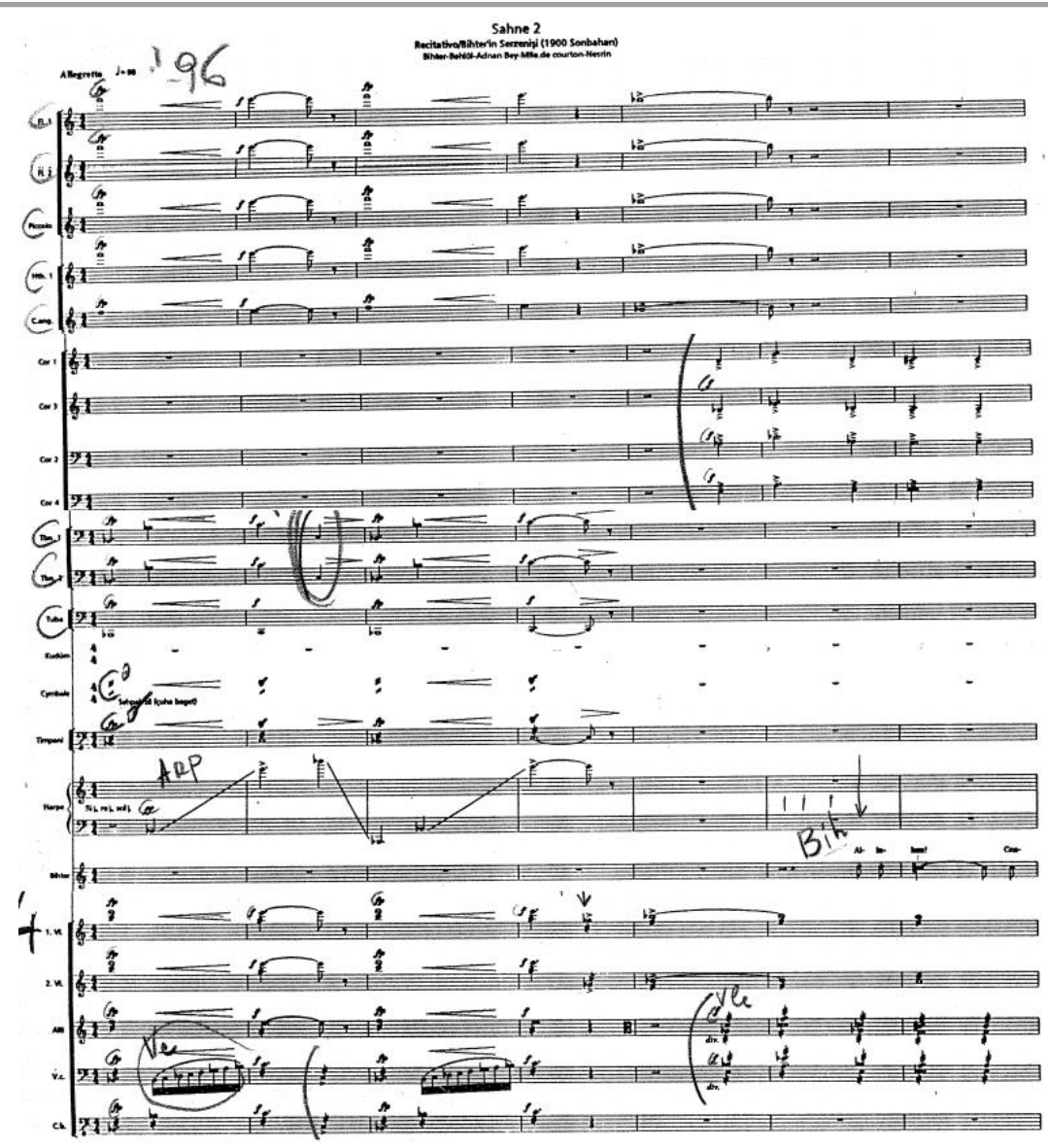

Nota 10: İkinci Perde İkinci Sahne’nin girişi.

İlerleyen ölçülerde "Je t'aime Adnan!" adlı arya başlar. Arya'nın başında ritmik yapıya yönelik olarak "düyek" teriminin kullanılması ilginçtir. Besteci bu terimle Türk müziğindeki düyek usulünü işaret etmekle birlikte, bahse konu usulün vuruşlarını gösteren bir nota örneğini de piyanoşan uyarlamasına eklemiştir. Özkan (2006, s. 633) düyek usulünü şöyle göstermektedir:

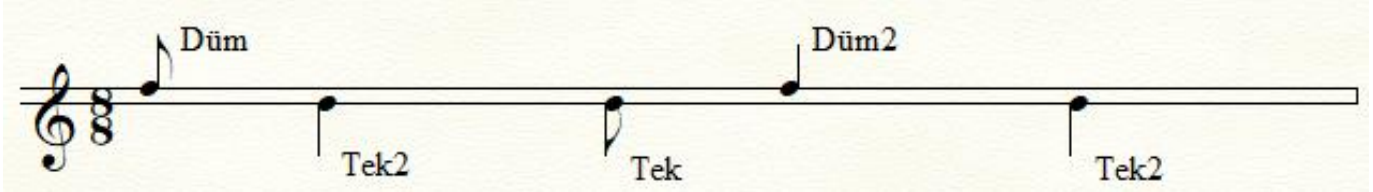

Nota 11: Düyek Usulü.

Besteci, "Je t'aime Adnan!" aryasının başlığı altına "Fransızca Bir Osmanlı Şarkısı" notunu düşmüştür. Arya'yı Mlle.de Courton, Fransızca olarak seslendirmektedir. Arya'nın eşliği ağırlıklı olarak do-mi-sol ve fa-lab-do akorlarından oluşur. Bu akorlar üzerinde, Mlle.de Courton'un seslendirdiği ezgi çizgisinde ise do majör dizi seslerinin ikinci, altıncı ve yedinci derecelerinin yarım ses pesleştirilmesiyle ortaya çıkan do, reb, mi, fa, sol, lab, sib sesleri işlenir. 


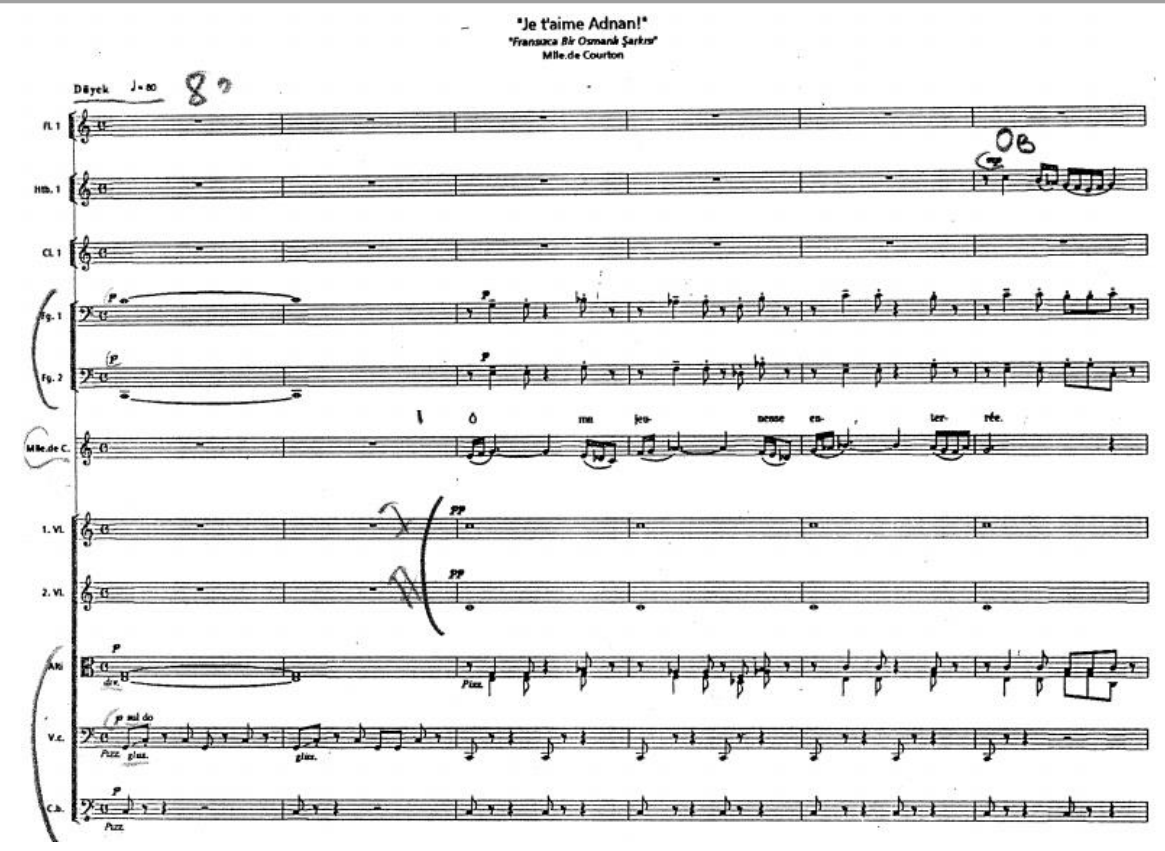

Nota 12: İkinci Perde İkinci Sahne'deki “Je t’aime Adnan” adlı aryanın 1-6. ölçüleri.

Hafiyelerin yer aldığı İkinci Perde Üçüncü Sahne, moderato tempoda, 4/4'lük ölçü birimi üzerinde başlar. Bu sahnede kamçı'nın enstrüman gibi kullanılması dikkat çekicidir. Do kararlı Nev'eser makamı dizi sesleri, zaman zaman ikinci derecesi yarım ses pesleştirilerek kullanılır. Sahnenin girişinde kontrbasların kalın ses bölgelerinde küçük ikili aralıklardan oluşan çift sesleri duyurması oldukça dikkat çekicidir. Bu örgüde kemanlar ve viyolalar ise artmış dörtlü ve tam dörtlü aralıklarının üst üste bindirildiği akorları, sekizlik süre değerleriyle seyrekçe seslendirir.

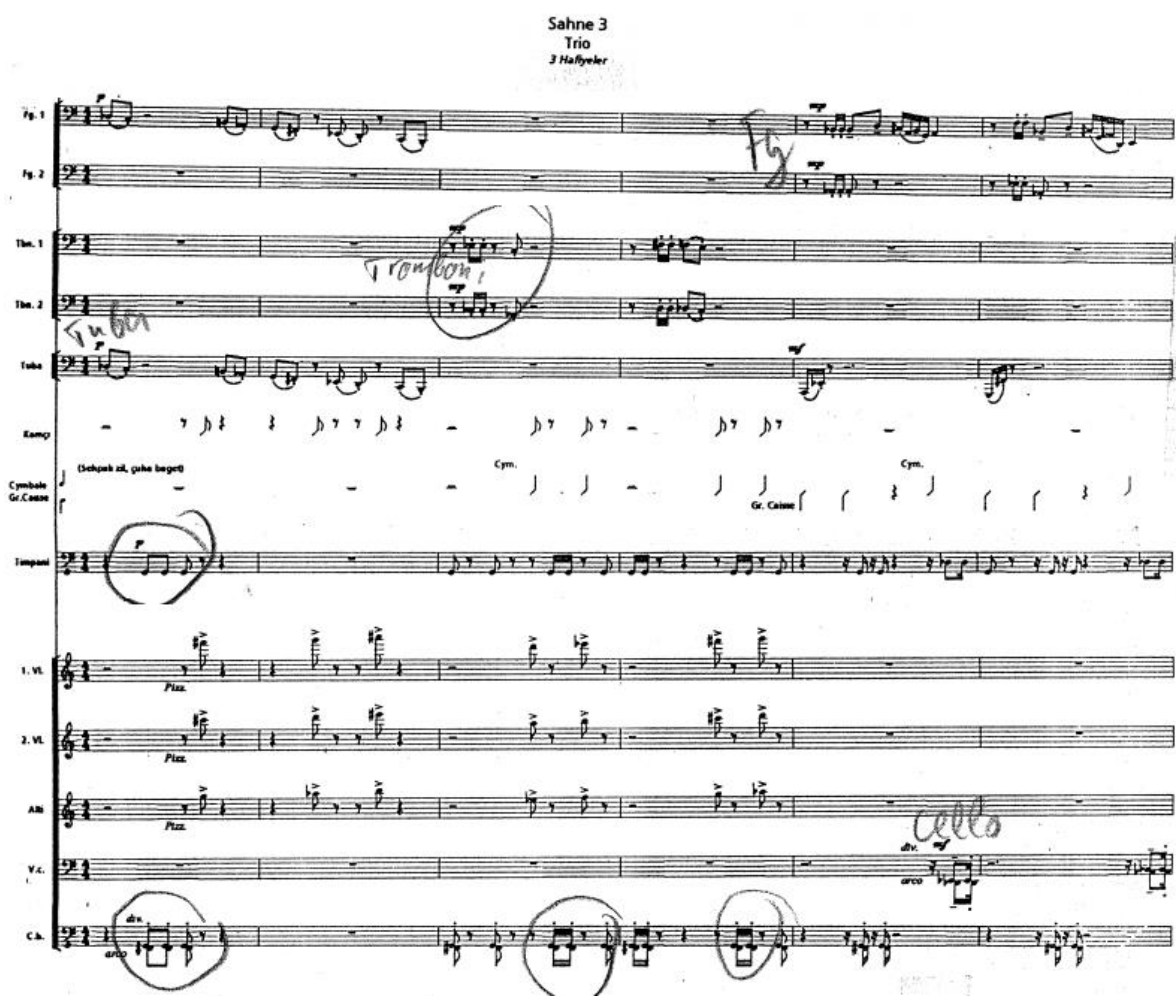

Nota 13: İkinci Perde Üçüncü Sahne'nin 1-6. ölçüleri. 
Nihal ile Behlül'ün flörtünü konu alan İkinci Perde Dördüncü Sahne, Nihal'in seslendirdiği Genç Kızlık Aryası'yla başlamaktadır. Arya, moderato tempoda 4/4'lük ölçü birimi üzerinde ilerler. Yaylı çalgıların pizzicato eşliğinde I. klarnet, makamsal renkler barındıran bir ezgi seslendirir.

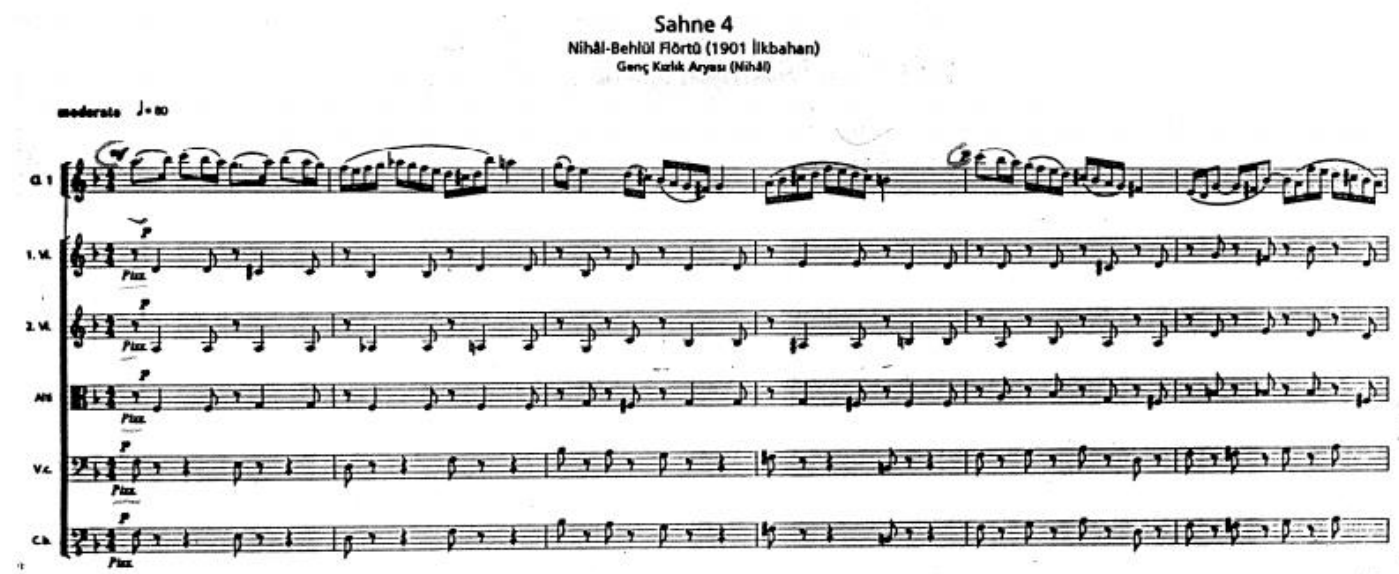

Nota 14: İkinci Perde Dördüncü Sahne'nin girişi.

İkinci Perde Dördüncü Sahne'nin ilerleyen bölümlerinde yer alan Firdevs Hanım'ın kantosu, biçim ve kök olarak opera da ördüğümüz diğer türlerden farklıdır. Ünal (2017, s. 259) kantonun tuluat tiyatrolarında, oyundan önce, genellikle kadın sanatçıların şark1 söyleyip dans ederek yaptığ gösteri ve bu gösteri sırasında söylenen coşkulu şarkılar olarak ortaya çıktığını belirtmiş ve kelime olarak da İtalyanca "şark1 söylemek" anlamına gelen "cantare" fiilinden türediğini aktarmıştır. Yazıcı ve Gökbudak (2015, s. 597), bestecinin bu aryayı "Kanto" olarak isimlendirmiş olmasına rağmen kantonun bilinen 9/8'lik ölçü birimi yerine, 12/8'lik ölçü biriminin kullandığını belirtir. Kanto, do majör tonunda, presto tempoda, 12/8'lik ölçü birimi üzerinde sekizlik süre değerinin egemen olduğu bir örgüyle başlar. Kanto'nun girişinde kontrbas, viyolonsel, fagot ve tom tom'un eşliğinde; flüt, keman ve viyolalar kromatik işlemelerin sık kullanıldığ hareketli bir ezgiyi seslendirirler. 


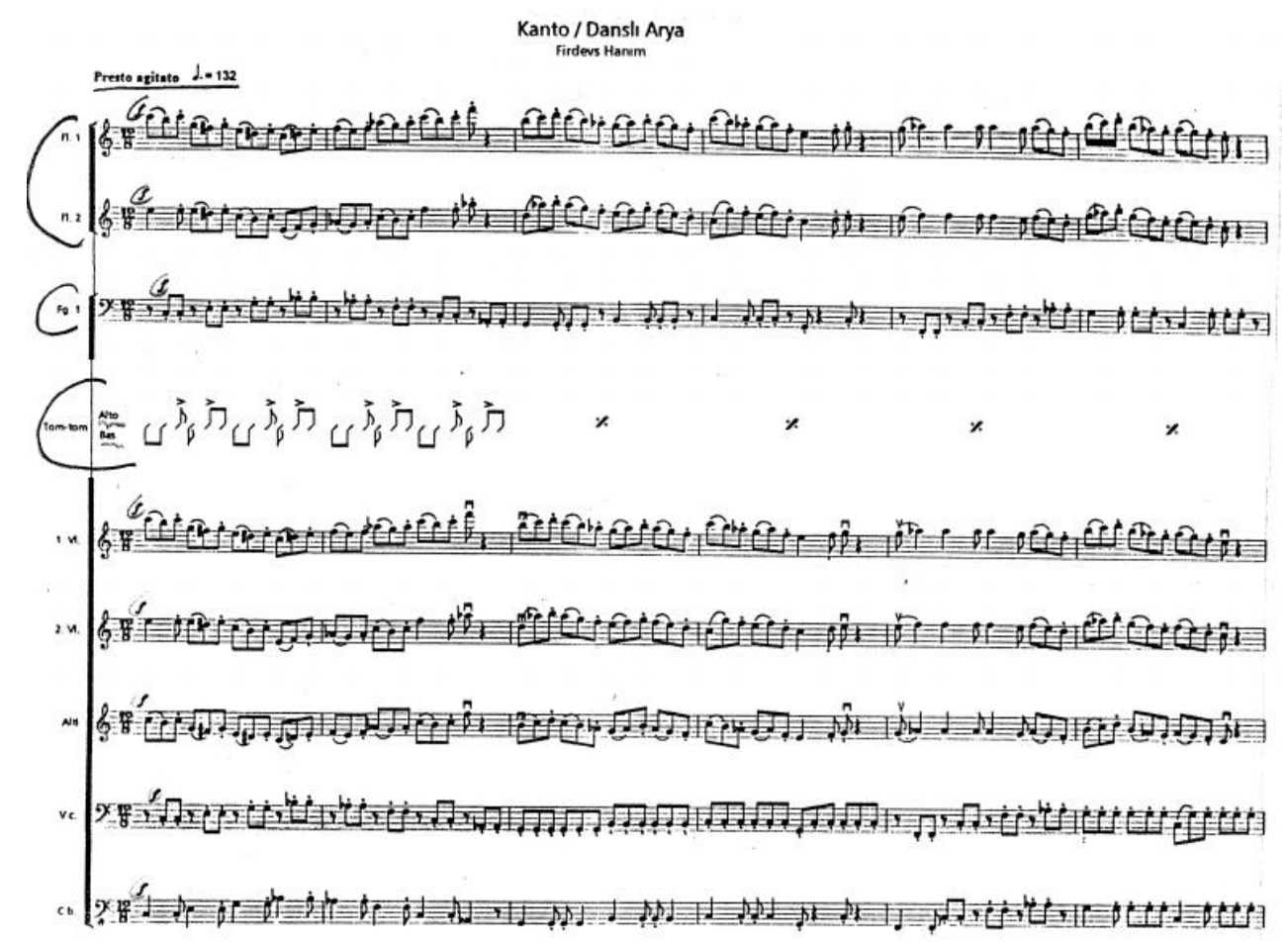

Nota 15: Firdevs Hanım'ın seslendirdiği Kanto/Danslı Arya'nın 1-6. ölçüleri.

İkinci Perde Dördüncü Sahne'nin sonunda, Adnan Bey ve koronun seslendirdiği Maskeler Aryası yer almaktadır. Kürdi makamı dizi sesleri ile yazılmış olan bu Arya'nın armonik eşliği, üçlü anlayıştadır. I. flüt ve obua, Arya'nın girişinde, arp ve viyolonselin sade eşliği üzerinde, yumuşak ve pastoral nitelikli bir ezgi seslendirmektedir.

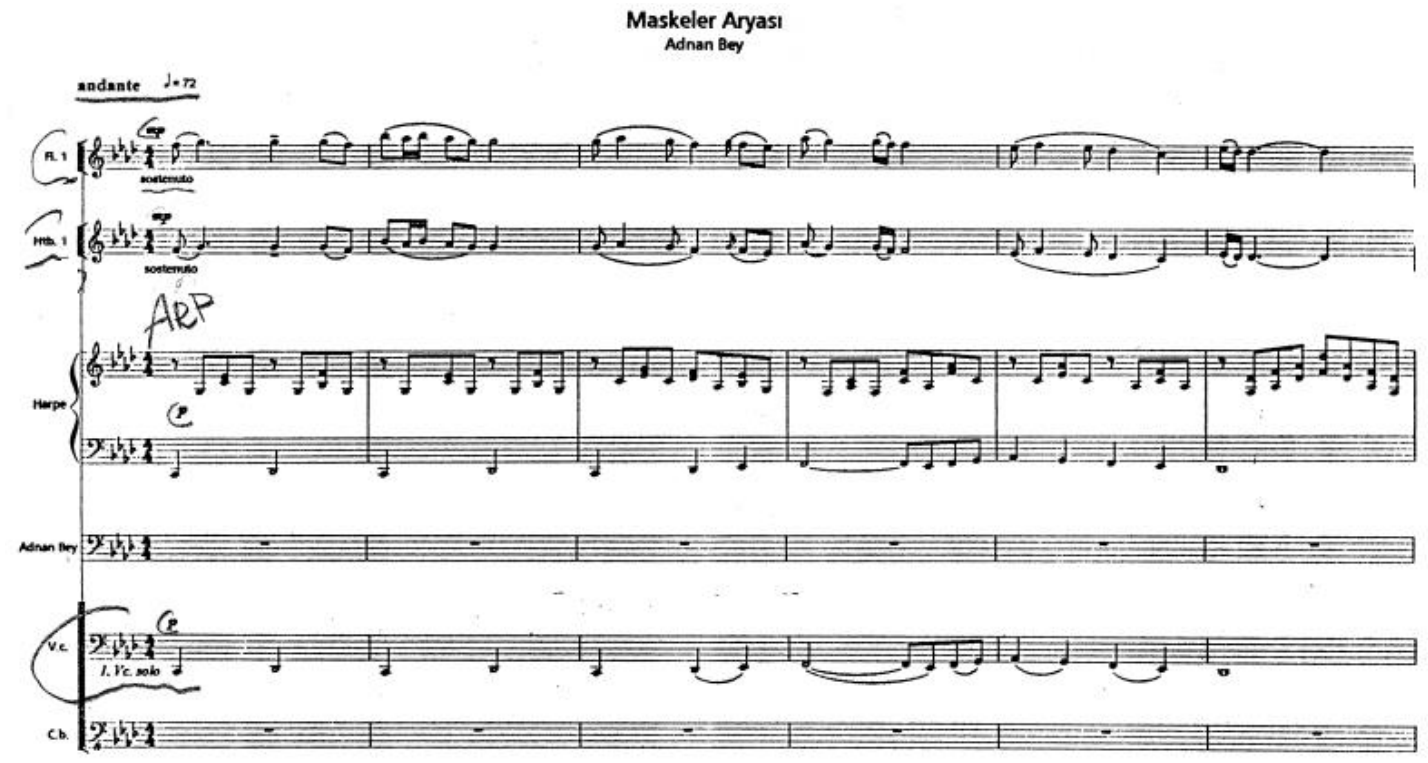

Nota 16: Maskeler Aryası'nın girişi.

İkinci Perde Beşinci Sahne, bestesi Lavtacı Hristo, güftesi Yahya Kemal Beyatlı'ya ait olan Kürdîlihicazkâr makamında ve aksak usuldeki Gidelim Göksu'ya adlı şarkı ile başlar. Do kararlı başlayan bu şarkıyı; yaylılar, flüt ve tomtom'un eşliğinde koro seslendirmektedir. 


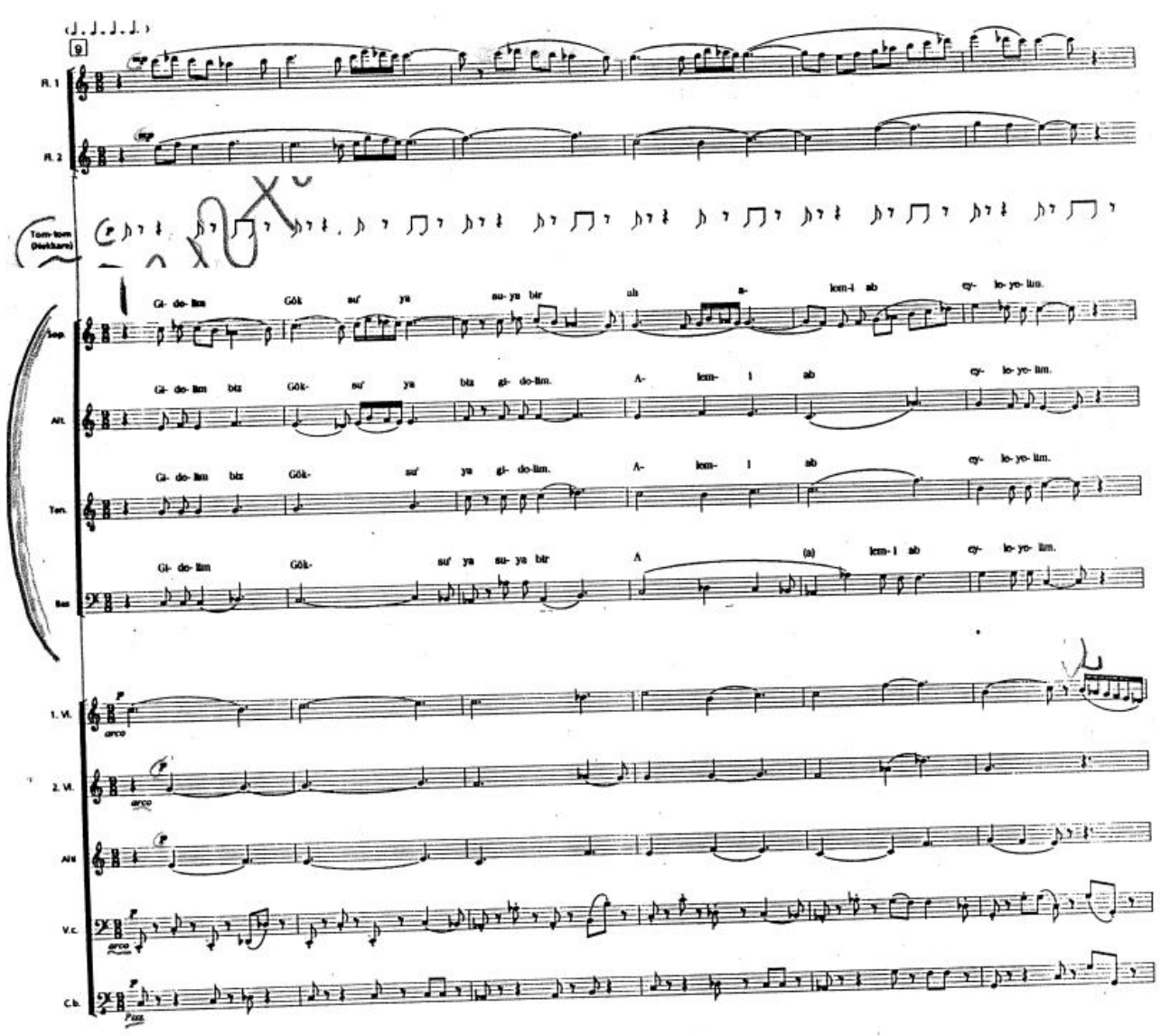

Nota 17: Gidelim Göksu'ya adlı şarkının 9-14. ölçüleri.

Gidelim Göksu'ya adlı şarkıyı müteakiben Vals ve İntihar bölümleri seslendirilir. Ardından Koral bölümde, orkestranın $f f$ nüansında seslendirdiği do minör akoru üzerinde, koronun "Gidelim Göksu'ya! Ne Hayat! Ah!” sözleri ile Aşk-ı Memnu sona erer.

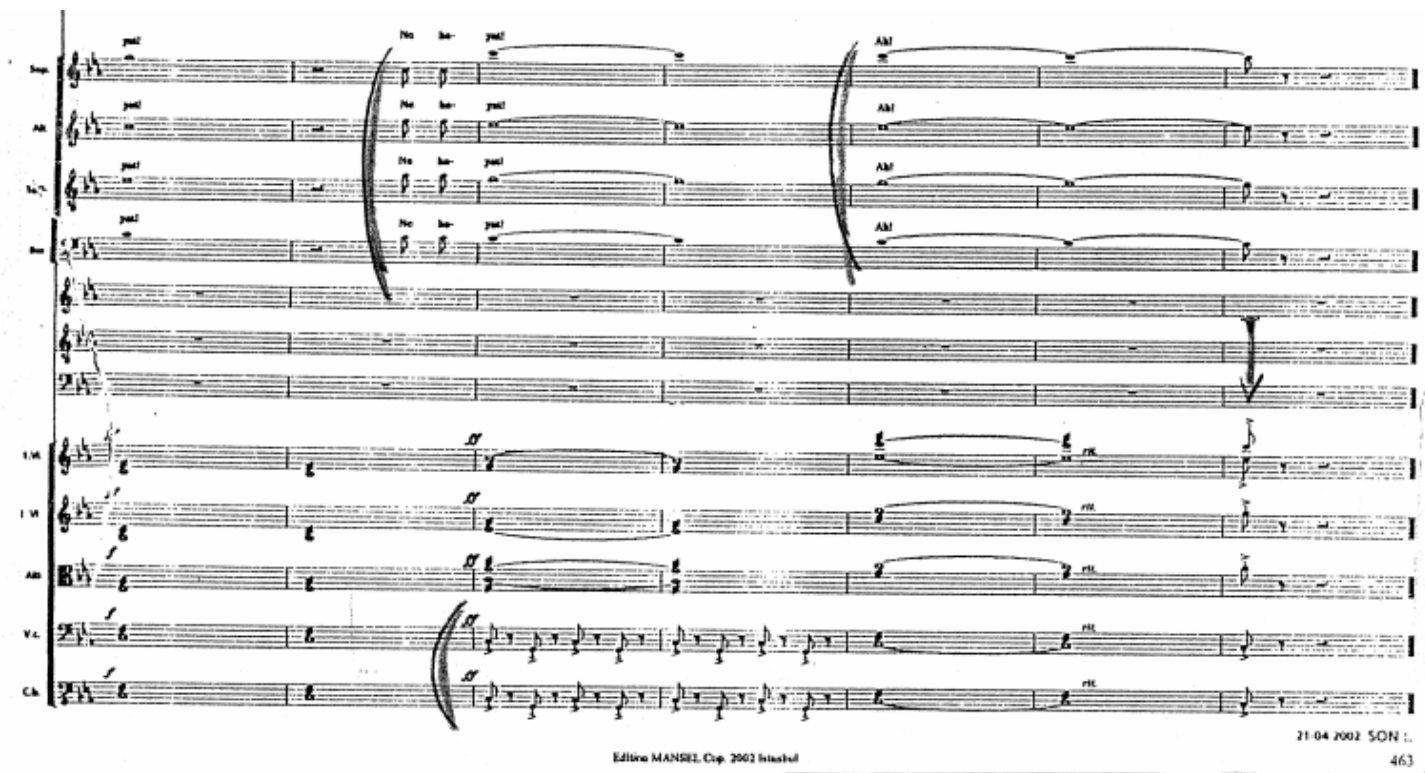

Nota 18: Aşk-ı Memnu'nun son 7 ölçüsündeki koro ve yaylı çalgılar partisi. 
Aşk-ı Memnu'da, herhangi bir akım ya da üslupla bağdaştırılamayacak nitelikte, özgün bir müzikal işçilik göze çarpar. Armonik zeminde ağırlıklı olarak tonal ama kendine özgü; kimi zaman da dörtlü ve ikililerin egemen olduğu bir anlayış görülür. Yapıttaki melodist yaklaşım ve bu coğrafyaya ait müzikal malzemeler, dinleyicinin eseri takip etmesini kolaylaştırmaktadır. Olay örgüsünün ilerleyişinde bir "duraklama” (pause) olarak değerlendirilebilecek aryaların ise bastan, sopranoya insan sesinin bütün registerlerini değerlendirecek şekilde geniş bir yelpazede tasarlandığı görülür. Aşk-ı Мemnu operasında toplam 13 arya bulunmaktadır. Bu aryalar: Kadınlar Aryası (Behlül), Kul Köle Aryası (Nesrin), Hürriyet Aryası (Adnan Bey), İffet Aryası (Bihter), Arzu Aryası (Bihter), Ebedi Bahar Aryası (Behlül), Veda Aryası (Beşir), Je t'aime Adnan Aryası (Matmazel), Entrika Aryası (Firdevs Hanım), Genç Kızlık Aryası (Nihal), İzdivaç Teklifi Aryası (Behlül) Bedbahtlık Aryası (Bihter), Maskeler Aryası (Adnan Bey-Koro). Diğer operalarla karşılaştırıldığında Aşk-ı Memnu'da, arya sayısının fazlalığı dikkat çekmektedir. Aşk-ı Memnu bu yönüyle yer yer operet estetiğine yaklaşmaktadır.

Reçitatif, arya, düet gibi klasik formların yanı sıra vals, kanto gibi danslar; semai, düyek gibi Türk müziği usulleri ve Yine Bir Gülnihal, Havada Bulut Yok, Gidelim Göksu'ya gibi doğrudan alınan şarkılardan oluşan Aşk-ı Memnu operasının biçimsel kurgusu, mozaik yapıda, renkli ve zengindir. Yapıta doğrudan dâhil edilen şarkıların, bestecinin yaratıcılık süzgecinden geçirilerek özgün bir üslupla sunulduğu görülmektedir.

Dinleyiciyi hemen kavrayabilen ezgi çizgisinde Nikriz, Nev'eser, Karcığar gibi çeşitli makam dizi seslerinin incelikle işlendiği görülür. Bu makamların dışında, Yazıcı ve Gökbudak (2015, s. 594), Aşk-ı Мemnu operasında Nihavend, Hicaz, Rast, Segâh, Kürdi, Kürdîlihicazkâr, Hicazkâr, Hüzzam, Hüseyni, Şehnaz, Buselik, Nişabür, Suzinak ve Zirgüleli Hicaz makam dizi seslerinin de kullanıldığı tespitini yapmaktadır.

Orkestra kadrosunda, senfoni orkestralarınının geleneksel enstrümanları yanında zilli def, kudüm gibi Türk müziği enstrümanlarına yer verilmesi ve kamçı gibi malzemelerin de enstrüman gibi kullanılması oldukça dikkat çekicidir.

Ritmik yapısı bağlamında ele alındığında $A s ̧ k-\iota ~ M e m n u$ 'da; aksak tartımlar, simetrik olmayan ritm kalıpları gibi bu coğrafyanın müzikal malzemelerine esaslıca yer verildiği görülmektedir. Bunun yanında ölçü biriminin sıklıkla değiştirilmesi de, yapıttaki ritmik yapıyı zenginleştirmektedir.

\section{Sonuç ve Öneriler}

Aşk-ı Meтnи operasının müziği, dramatik yapısı ve karakterlerinin, aynı adlı romanla karşılaştırılarak incelendiği bu çalışmada, elde edilen verilerden şu sonuçlara ulaşılmıştır:

Uşaklıgil, siyasî ve dinî baskıların devam ettiği bir dönemde, döneminin ruhu nedeniyle bu iki konuya değinmeden toplum yerine bireyleri ön plana çıkararak sınırlı bir mekânda hikâyesini kurgulamıştır. Tarık Günersel'in yazdığı librettoda ise dönemi gereği Halit Ziya Uşaklıgil'in değinemediği toplumsal ve siyasî konulara değinildiği görülür. Baskıcı yönetim açık açık vurgulanır. Örneğin Opera'da evlenme merasimi biter bitmez Adnan Bey, hafiyeler tarafindan "okumak" suçlamasıyla tutuklanmaktadır.

Aşk-ı Memnu bağlamında Roman ve Opera arasındaki en önemli fark, Adnan Bey ve ailesinin yaşam tarzıdır. Adnan Bey ve ailesi Roman'da Batı'lı bir hayat tarzına sahip iken Opera'da muhafazakâr bir hayat yaşamaktadır. Roman'da yer almamasına karşın Opera' da Bihter ile Adnan Bey'in nikâhının bir imam tarafından kıyılması bu konudaki örneklerden biridir.

Selman Ada, Aşk-ı Memnu operasında çok iyi bildiği Batı müziği malzemeleri ile yaşadığı coğrafyanın müzikal malzemelerini ortak paydada ustaca birleştirerek, kıymeti bir operayı ulusal opera repertuvarımıza kazandırmıştır. Aşk-ı Memnu'da olay örgüsü ile uyumlu bir şekilde ilerleyen, dramayı ve duyguları destekleyen bir müzikal yaklaşımın gözetildiği söylenebilir. Ada'nın, 
herhangi bir akım ya da üslupla bağdaştırılamayacak nitelikteki özgün müzikal işçiliği dikkat çekicidir.

Dinleyiciyi çabuk sarabilen ezgi çizgisinde Segâh, Rast, Nev’eser, Kürdi, Nikriz ve Karcığar gibi Türk müziği makam dizi seslerinin incelikle işlendiği görülür.

Armonik düzlemde genelde tonal ama kendine özgü; kimi zaman da dörtlü ve ikililerin egemen olduğu bir anlayış görülür. Yapıttaki melodist yaklaşım ve Türk müziğine ait unsurlar, operanın takip edilmesini kolaylaştırmaktadır. Olay akışında bir "duraklama" (pause) olarak değerlendirilebilecek aryaların diğer operalara kıyasla sayıca fazlalığı dikkat çekicidir. Bu yönüyle Aşk-ı Memnu'nun operet estetiğine yaklaştığı da ifade edilebilir.

Vals, kanto gibi dansların; semai, düyek gibi Türk müziği usullerinin ve Yine Bir Gülnihal, Havada Bulut Yok, Gidelim Göksu'ya gibi bilinen eserlerin Opera'ya dâhil edilmesi, mozaik ve zengin bir biçimsel yapının elde edilmesinde oldukça etkili olmuştur. Türk müziğinin karakteristik özelliklerinden biri olan aksak tartımlar da Aşk-ı Memnu' da esaslı olarak kullanılmıştır.

Batı ve Doğu bileşiminin yansımaları orkestra kadrosunda da görülür. Orkestrada, Batı müziği çalgılarının yanında zilli def, kudüm gibi Türk müziği çalgılarına da yer verilmiştir. Bazı sahnelerde kamçının enstrüman gibi kullanılması da orkestrasyon konusundaki ender uygulamalardandır.

İlk "gerçek" Türk romanı ve edebiyatımızın şaheserlerinden biri olan Aşk-ı Memnu, ülkemizin en önemli bestecilerinden Selman Ada'nın ilham kaynağı olmuştur. Bu doğrultuda diğer bestecilerimizin de, edebiyatımızın önemli eserlerini konu alan kompozisyonlarının incelenmesinin; inceleme neticesinde elde edilen sonuçların ulusal ve evrensel kültürün hizmetine sunulmasının, bestecilerimizin düşünsel dünyalarını zenginleştireceği ve disiplinler arasındaki bağları kuvvetlendireceği değerlendirilmektedir.

\section{Kaynakça}

Arslanoğlu Yıldıran, A. (2017). Așk-1 Memnu: Yitik cennetler. Uluslararası Kültürel ve Sosyal Araştırmalar Dergisi (UKSAD), 3(2), 251-262.

Kanan, Meriç S. (2007). Aşk-ı Memnu program dergisi. Ankara Devlet Opera ve Balesi Yayınları Say1: 9.

Kantemir, E. (2019). Aşs-1 Memnu (eser incelemesi). Ankara University Journal of Faculty of $\begin{array}{llll}\text { Educational } & \text { Sciences } & \text { (JFES), } & \text { 227-239. }\end{array}$ https://dx.doi.org/10.1501/Egifak.0000000798

Maden, S. (2008). Aşk-1 Memnû ve Madam Bovary romanlarında kadınların yönlendirdiği olay örgüsü. Türklük Bilimi Araştırmalarl, (24), 79-97.

Moran, B. (1998). Türk romanına eleştirel bir bakış 1. İletişim Yayınları.

Özkan, İsmail H. (2006). Türk mûsıkîsi nazariyatı ve usûlleri kudum velveleleri. Ötüken Neşriyat.

Şahin, S. (2010). Romandan tiyatroya Aşk-1 Memnû. Folklor/Edebiyat, 16(4), 121-130.

Uşaklıgil, Halit Z. (2020). Aşk-ı Memnu. Can Yayınları.

Ünal, G. (2017). Batı-dışı modernlik kavramı bağlamında Kanto. Online Journal Of Music Sciences, 2(3), 247-269.

Yazıcı, H. \& Gökbudak, Z. (2015). Aşk-1 Memnu operasında ulusalcığa ilişkin unsurlar. EKEV Akademi Dergisi, 62(62), 585-600. https://dx.doi.org/10.17753/Ekev419 